\title{
Development of a Software System for Selecting Steam Power Plant to Convert Municipal Solid Waste to Energy
}

\author{
Rotimi A. Ibikunle ${ }^{1, * \mathbb{C}}$, Isaac F. Titiladunayo ${ }^{2}$ and Basil O. Akinnuli ${ }^{3}$ \\ 1 Department of Mechanical Engineering, College of Engineering, Landmark University, PMB 1001, Ipetu Road, \\ Omu-Aran 251103, Nigeria \\ 2 Department of Mechanical Engineering, School of Engineering, Federal University of Technology, PMB 704, \\ Akure 340106, Nigeria; ftitiladunayo@yahoo.com \\ 3 Department of Industrial and Production Engineering, School of Engineering, Federal University of \\ Technology, PMB 704, Akure 340106, Nigeria; ifembola@yahoo.com \\ * Correspondence: ibikunle.rotimi@lmu.edu.ng
}

Citation: Ibikunle, R.A.;

Titiladunayo, I.F.; Akinnuli, B.O.

Development of a Software System

for Selecting Steam Power Plant to

Convert Municipal Solid Waste to

Energy. Sustainability 2021, 13, 11665.

https://doi.org/10.3390/su132111665

Academic Editors: Rita Khanna,

Yury Konyukhov and

Igor Burmistrov

Received: 2 August 2021

Accepted: 31 August 2021

Published: 21 October 2021

Publisher's Note: MDPI stays neutral with regard to jurisdictional claims in published maps and institutional affiliations.

Copyright: (c) 2021 by the authors. Licensee MDPI, Basel, Switzerland. This article is an open access article distributed under the terms and conditions of the Creative Commons Attribution (CC BY) license (https:// creativecommons.org/licenses/by/ $4.0 /)$.

\begin{abstract}
A software system that enhances the selection of appropriate power plant capacity that will convert combustible municipal solid waste (MSW) into energy was developed. The aggregate of waste to be converted was determined and the corresponding heating value was established. The capacities of steam power plants' components required for the conversion were determined, using thermodynamic mathematical models. An algorithm based on models used to determine the energy potential, the power potential of MSW, the capacities of the components of the steam power plant, were translated into computer soft code using Java programming language; saturated steam and superheated steam tables, together with the thermodynamic properties of the power plant required were incorporated into the soft code. About 584 tons of MSW having a heating value of $20 \mathrm{MJ} / \mathrm{kg}$ was the quantity of waste experimented for energy generation. This information was input into the software as data and was processed. Then, the software was able to predict $3245.54 \mathrm{MWh}$ energy potential for the quantity of waste, and electrical power potential of $40.54 \mathrm{MW}$. The capacities of the steam power plant components that were predicted include 100.35 MW of boiler power, $40.54 \mathrm{MW}$ of turbine power, and 59.80 MW of condenser power. The methodology adopted will make it easy for the managers in the waste-to-energy sector to appropriately select the suitable capacity of the required steam power plant that can convert any quantify of MSW at any geographical location, without going through the engineering calculation and stress or rigor involved in the plant capacity design. Moreover, the accuracy obtained for the software is greater than $99 \%$.
\end{abstract}

Keywords: decision support system; combustible MSW; energy potential; power potential; selection of power plant

\section{Introduction}

Municipal solid waste (MSW), is a collection of materials resulted from man's activities with his environment on daily basis, which are considered as not useful and are disposed of as wastes. MSW generation is on the high side over the years, around the globe, due to the increase in population, changes in taste, fashions, advancement in technology, and consumerism growth [1,2]. Islam [3] and Ibikunle [4,5] reported that the growth in MSW generation is due to the global quest for urbanism, social, and industrial development. Johari [6] stated that the sporadic increase in a waste generation will necessitate environmental challenges unless it is adequately and promptly managed. Ibikunle [7] remarked that the waste generated in the Ilorin metropolis of Kwara State is a huge one, and the waste management system available is insufficient; this makes people indulge in indiscriminate disposal of wastes which results in pollution, an unsightly scene, and blockage of waterways. 
The global record on MSW production showed a generation rate of 680 million tons/annum in the year 2000 and it increased to 1300 million tons/annum in the year 2010. A projection of 2200 million tons/annum was made for the year 2025 while 4200 million tons/annum was projected for the year 2055 [8]. The rate of waste generation (MSW/capita/ day) is a principal environmental pressure indicator required to estimate the intensity of waste generation for effective management planning [7]. Moreover, it is also useful in comparison of the degree of MSW generation between a nation and another. In the United Kingdom, the MSW rate of generation was recorded to be $1.34 \mathrm{~kg} / \mathrm{capita} /$ day, $2.13 \mathrm{~kg} /$ capita/day for the United States, $2.00 \mathrm{~kg} /$ capita/day for South Africa, $0.09 \mathrm{~kg} /$ capita/day for Ghana, and $0.58 \mathrm{~kg} /$ capita/day for Nigeria, according to Parashar [9]. Nevertheless, Ibikunle [7] reported the rate of MSW production in the Ilorin metropolis to be $0.78 \mathrm{~kg} /$ capita/day, which is $20 \%$ greater than the rate estimated for waste production in Nigeria in 2016. The rate of growth in waste production in the nations is quite alarming, and this poses a threat for the waste management system especially in the Ilorin metropolis $[7,10]$.

Lately, there is a growth in the power generation (technology) sector, utilizing renewable resources as an energy basis. Despite the development and expansion in power technology by utilizing renewable resources, $41 \%$ of Nigeria still does not have access to electricity [11]. This means only about 115 million Nigerians have access to electricity, out of about 196 million. Wind, hydro, solar, and biomass are the most utilized renewable energy resources for energy production throughout the globe, since the drive for sustainable and renewable energy [12]. It was reported by Ogunjuyigbe [13] and Ibikunle [4] that recovery of clean energy from MSW will promote a clean and green living environment for the growth of a nation and the standard of living of her citizens.

The governments of many nations are strategizing to have the rate of renewable energy (RE) generation increase by reducing costs while ameliorating the rate of greenhouse gases (GHGs) emission and fossil fuels dependence. This will ensure a clean and green environment, clean energy, and green industry, and the availability of more job opportunities and the like [14]. Fundamentally, energy is required as a strategic resource in the foundation formation for social and economic development. However, the rapid demographic growth and socio-economic development require high demand for energy [15]. It is predicted that the global demand for primary energy in 2050 will increase by $80 \%$, which will pose a threat to energy security [16]. There is quite a large demand for power that is characterized by supply that does not satisfy the domestic and commercial demand. The need to secure new renewable energy and power sources is a principal global concern because of the constant depletion of fossil fuels. Moreover, it is a compulsory task now to ameliorate the emission of carbon dioxide $\left(\mathrm{CO}_{2}\right)$ the prominent greenhouse gas (GHG) because of its consequential effect on climate change [2,17].

However, in urban cities of both developing and underdeveloped nations, there is always a massive generation of MSW, which is associated with the standard of living in metropolitan cities. Efficient management of MSW in most cities of Nigeria is a big issue $[18,19]$. In May (2019), the worldometer [20] reported the population of China to be 1418 million people, US-328 million, Japan-126 million, Germany-82 million, UK66 million, and France-65 million people. The MSW generation in China is 46 million tons/year, in the US it is 262.4 million tons/year, Japan is 44 million tons/year, Germany is 51 million tons/year, the UK is 32 million tons/year, and France is 33 million tons/year [21]. Worldometer in May 2019 reported the population density of Nigeria, Ethiopia, Egypt, Tanzania, and South Africa to be 196 million, 108 million, 99 million, 59 million, and 57 million respectively. According to Kosuke [22], South Africa has a generation rate of $2.0 \mathrm{~kg} /$ capita/day, Nigeria has $0.58 \mathrm{~kg} /$ capita/day, Ethiopia has $0.3 \mathrm{~kg} / \mathrm{capita} /$ day and Tanzania has $0.26 \mathrm{~kg} /$ capita/day. Therefore, by appropriation based on the generation rate and the population density, the MSW generated in Nigeria was estimated to be 42 million tons/year, Ethiopia was 12 million tons/year, Egypt was 44 million tons/year, Tanzania was 6 million tons/year, and South Africa was 42 million tons/year. 
The number of power plants in China, US, Japan, Germany, the UK, and France is $166,88,822,78,14$, and 37 respectively; while power generation in China is 18.7 million MWh, US is 14 million MW, Japan is 1.9 million kWh, Germany is 5768 GWh, the UK is 2782 GWh and 1999 GWh is in France [23]. Despite the enormous waste generated in African nations, and the recent development in WTE technology, Africa is still behind in waste-to-energy (WTE) practices. The first waste-to-energy (WTE) power plant in Africa is $110 \mathrm{MW}$ of Ethiopia, and Ghana is proposing a $60 \mathrm{MW}$ Armech thermal power plant [24]. Oladende [25] reported that the Nigeria Electricity Supply Industry (NESI) has 12 power stations in Nigeria with a total power output of 11,165 MW and yet could not produce power during an off-peak period of the Christmas holiday; moreover, the only 26,000-L capacity biogas power plant, at Ikosi-Ketu market in Lagos, with about 10 KVA daily capacity, has not commenced operation. In South Africa, the renewable energy project put in place by the renewable independent power producer procurement programme (REIPPPP) is about $6327 \mathrm{MW}$ altogether, in which landfill and biogas take $60 \mathrm{MW}$ altogether [26]. The Ilorin metropolis that is selected for this study produces 302,000 tons of MSW per year, with a generating rate of $0.78 \mathrm{~kg} /$ capita/day; $70 \%$ of the aggregate waste generated is combustible, yet the city still faces an energy crisis [7]. The power supply by the Power Holding Company of Nigeria (PHCN) to the Ilorin metropolis is insufficient for her social and economic demand. Therefore, if energy recovery from waste components is adopted in Ilorin, it will provide a dual solution viz., efficient waste management and provision of alternative energy to energy from fossil fuels, which can complement the power supply from PHCN.

To practice WTE in any environment, the sufficiency and efficiency of the waste fractions required must be ascertained; the sufficiency of MSW is about the quantity of the waste fractions available for energy production and the regular flow in terms of the generation rate. The efficiency of waste is about the heating value and the correlation between the physicochemical properties of the MSW and its calorific value. When the sufficiency and the efficiency of the waste have been determined, then the choice of the appropriate WTE technology can be made. In this study, software was developed using Java programming language, an algorithm based on equations used to determine energy potential and electrical power potential of the municipal solid waste. The mathematical models used to determine the capacity of each of the equipment in the waste-fired power plant was prepared, which is translated into computer soft code using Java programming language, which is one of the common programming languages used in numerical analysis as well as a unified modeling language (UML) [27].

This study aims to provide software that will serve as a management and technical decision tool, to predict the capacity of steam power equipment that will convert MSW into energy at any geographical location, provided the available quantity of waste for energy and the low heating value (LHV) is also established. This study solves one of the technical challenges that could be encountered while trying to ascertain the capacity of the plant required. Nevertheless, the software developed in this study will predict the available energy and power potential in the waste to be converted, as well as the thermodynamic properties of the stages involved in the process. This software is referred to as a power plant selection support system because it helps in taking decisions on the appropriate capacity of the steam power plant required for a specific quantity of waste when its low heating value has been ascertained. The accuracy of the software is established by comparing the calculated values to the values generated by the software, and it is found to be above $99 \%$.

\section{Decision Support Systems (DSSs)}

The computer-based interactive systems adopted to help the users to make the right decision or choice of activities and judgment are called DSSs; this is characterized by data bank and retrieval device. It enhances access to information and restoration of functions that support modeling and reasoning based on models. DSSs also support solving problems and framing. In most situations, the standard or quality of decisions 
taken can be used to correct the human error involved during decision-making. Disciplines that include operations research, economics, and statistics develop various methods for decision making. The methods can be enhanced by different scientific techniques that are based on artificial intelligence. Computer programs that either operate as tools on their own or as integrated computing environments are adopted for complex decisions. Such computing environments are called decision support systems (DSSs). The broad concept of a DSS is responsible for the variation in its definitions, therefore, every definition now depends on the author's point of view. To embrace all perspectives, a DSS can be defined as a computer-based system that aids users in judgment and choice of activities [28]. This is the reason the software developed in this study, to select the appropriate capacity of steam power plant that will convert any quantity of combustible MSW to energy in any geographical location, is considered as a decision support system.

The design of a DSS and its analysis is so complex that it involves the usage of specific and adequate instruments and methodologies to model the decision processes. Customized and developed features can be used to implement a DSS for decision activities or by utilizing a generalized DSS that can later be customized. DSSs can either be specifically developed for an establishment, using programming languages or using DSS generators. The strategy involved in the software development either engages general-purpose programming language (GPL), such as $\mathrm{C}++$, PASCAL, BASIC, or COBOL, or engages the use of fourth-generation language (4GL), such as VISUAL BASIC .NET, C\# .NET, VISUAL J\# .NET, DELPHI, JAVA, or VISUAL C++ [29]. The most appropriate area for the installation of a biomass power plant can best be selected by managers using a spatial decision support system. Fuzzy logic and fuzzy membership functions are used for the creation of criteria layers and suitability maps. Multicriteria Decision Analysis methodology (Analytical Hierarchy Process) combined with fuzzy system elements for the determination of the weight coefficients of the participating criteria are used [30]. Fatima [31] incorporated a decision support system in a power plant simulation tool to provide the qualitative synthesis needed for the plant design process, and to assist the design engineers in performing a better choice-evaluation for technical quantitative and qualitative analysis.

Konstantinos [32] stated that decision support systems (DSS) are an approach designed as a tool to help managers take decisions by accelerating the relevant processes. The DSS developed in this study is designed to accelerate processes required in the design of power plants, and concurrently predict the energy and power potentials available in a quantity of MSW. This DSS can predict the energy and power potentials of the MSW fractions that are available for power generation, predict the thermodynamic properties involved in each stage of the power cycle of the steam power plant, and also predict the capacity of each of the equipment in the power plant that will convert a particular quantity of MSW whose net heating value is known.

\section{Materials and Methods}

The MSW materials investigated in this article are the 9 combustible MSW fractions of the total 19 waste fractions identified in the Ilorin metropolis. These include paper, packaging boxes, grass/garden trimmings, rags, wood, food residue, nylon, polypropylene sacks, and plastic bottles. The quantity of the MSW available per day for energy production was established, and the net heating value was determined using an $e-2 k$ combustion calorimeter. The heat energy and the power potentials of the MSW were determined. Rankine reheat cycle was used to design the capacities of the steam power plant equipment required for energy production. The mathematical models utilized in determining the energy potential and the designing of the power plant capacity are used to form the algorithm used in the development of the software, called the decision support system. The software interfaces were developed using Java swing utilities that comprise JFrames, JTextrafields, JButtons, and JEditorpane for data display. Action listeners and action events were used to control the button functionalities, handle calculations, and panel/Editorpane displays [25]. 


\subsection{Determination of the Aggregate MSW Generated in Ilorin/Year, Using Collection Facts and Figures}

The aggregate MSW produced in the Ilorin metropolis of Kwara State between January and June 2021 was estimated by using the mathematical model in Equation (1), without the aid of a weighing bridge, as suggested by Kosuke [22] and Ibikunle $[4,5,10]$.

$$
\operatorname{MSW}_{\text {gen. }}=\sum_{j=1}^{365} \sum_{i=1}^{n}\left(C_{i} \times V_{i} \times d_{i} \times t_{i j}\right) \times(0.74)
$$

The total number of trucks is $n$, the capacity of a truck is $C_{i}\left(\mathrm{~m}^{3} /\right.$ truck), the loading volume ratio of a truck is $V_{i}$, the density of MSW loaded on the truck is $d_{i}$ (tons $/ \mathrm{m}^{3}$ ), and the number of trips by truck is $t_{i j}$ on day $\mathrm{j}$ (frequency of trips/day).

\subsection{Characterization of the MSW Fractions}

It was reported by NT ENVIR 001 [33], Issam [34], and Ibikunle [4,5,10] that the huge MSW collected from different locations in the city can be effectively characterized through random sampling of some selected heaps of wastes deposited in the dumpsite. NT ENVIR 001 [33] suggested that $240 \mathrm{~L}$ of a bin full of MSW are appropriate as a unit sample. The waste streams were characterized twice a week for six months, thereby making 48 different batches of samples for the characterization investigation at Lasoju dumpsite to avoid any consequences from the effect of insufficient samples. Each component identified was sorted into different receptacles and weighed.

\subsection{Physicochemical and Heating Value Analysis of MSW}

\subsubsection{Moisture Content Analysis of MSW Components}

The moisture content of the MSW combustible fractions was estimated using an electric oven (model DHG 9053) with a $200{ }^{\circ} \mathrm{C}$ capacity. About $1 \mathrm{~g}$ of powder of the sample of each component was measured into a crucible and dried in the oven, maintained at a temperature of $110^{\circ} \mathrm{C}$ for an hour. The weight loss is considered as the moisture content of the waste component as suggested by Vairam [35], Shi [36], Titiladunayo [7], and Ibikunle $[4,7,37]$ using Equation (2).

$$
M C=\frac{W_{2}-W_{3}}{W_{2}-W_{1}} \times 100
$$

where $M C$ is the percentage moisture content, $W_{1}$ is the mass of empty crucible $(\mathrm{g}), W_{2}$ is the mass of crucible and sample (g), $W_{3}$ is the mass of crucible and sample after heating (g), $W_{2}-W_{1}$ is the mass of sample (g), and $W_{2}-W_{3}$ is the moisture content $(\mathrm{g})$.

\subsubsection{Ultimate Analysis of MSW Components}

Ultimate analysis was investigated to ascertain the quantitative value of the carbon $(\mathrm{C})$, hydrogen $(\mathrm{H})$, nitrogen $(\mathrm{N})$, sulphur $(\mathrm{S})$, and oxygen $(\mathrm{O})$ percentage content that is available in the MSW components. The investigation was carried out using an elemental analyzer (Flash EA 1112 model), based on ASTM D5291. About $0.5 \mathrm{~g}$ of powdered sample of each component was measured into a crucible and combusted. The oxides of carbon, hydrogen, nitrogen, and sulphur produced were analyzed by thermal conductivity detector (TCD), and the electrical signal emerged was processed by 'Eager 300 software' to give the percentages of elements contained in the sample. The samples were replicated, and an average of the values obtained is considered as the typical value [2].

\subsection{Estimation of the Heating Value of the MSW Combustible Fractions}

Islam [3] and Shi [33] suggested that the high heating value (HHV) of solid fuel can be determined by using $e-2 k$ combustion calorimeter, shown in Figure 1 . The low high heating value (LHV) of the nine combustible waste fractions presented in Table 3 was obtained by 
applying Equation (3), as adopted by Islam [3], Ibikunle [4], Ibikunle [10], Ibikunle [37], and Kumar [38], as well as adopting Dulong and Steuer models in Equations (4) and (5) respectively. The average of the LHV obtained from the three equations is considered the typical LHV $[4,7]$.

$$
L H V^{i}=\sum_{1}^{9} W_{\mathrm{msw}}(\%) \times H H V_{\mathrm{msw}}
$$

where $W_{\mathrm{msw}}$ is the weight fraction (\%) of the combustible MSW and $H H V_{\mathrm{msw}}$ is the high heating value obtained by using a bomb calorimeter [4,10,37-39].

$$
\begin{gathered}
L H V^{i i}=81 C+342.5\left(H-\frac{\mathrm{O}}{8}\right)+22.5 S-6(\mathrm{~W}+9 H) \\
L H V^{i i i}=81\left(C-\frac{3}{8} \mathrm{O}\right)+57 \frac{3}{8} \mathrm{O}+345\left(\mathrm{H}-\frac{\mathrm{O}}{16}\right)+25 \mathrm{~S}-6(\mathrm{~W}+9 \mathrm{H})
\end{gathered}
$$

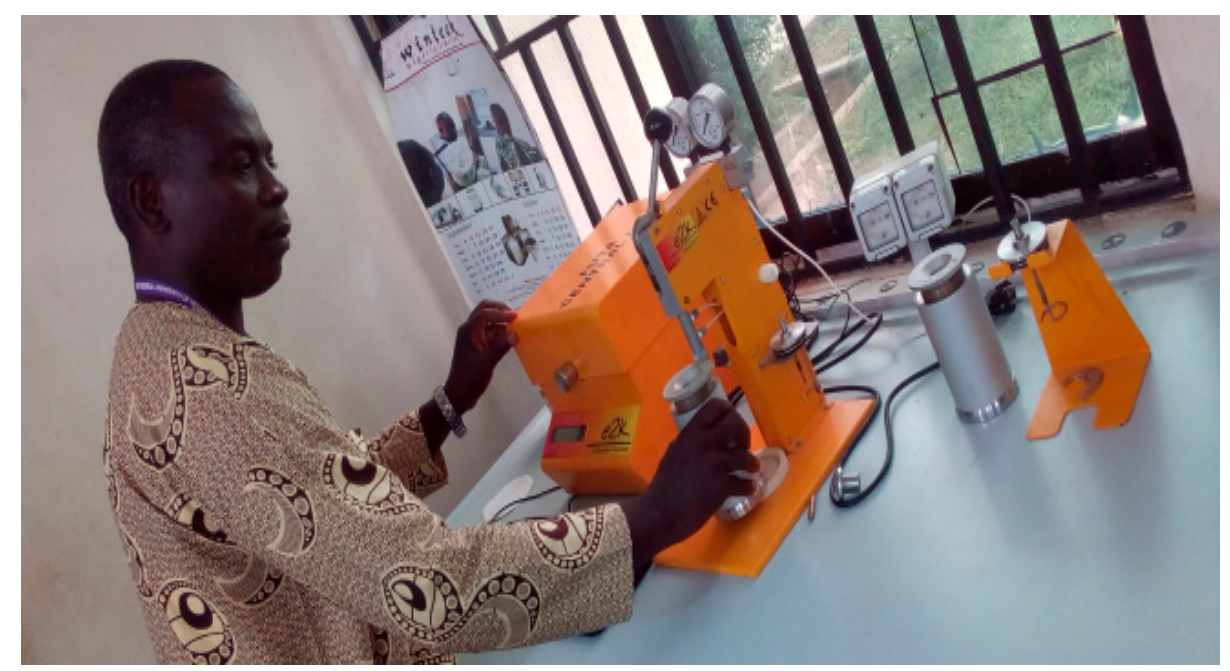

Figure 1. $e-2 k$ Combustion for HHV determination [27].

In Equations (4) and (5), $L H V^{i i}$ and $L H V^{i i i}$ are the heating values estimated by adopting Dulong and Steuer models respectively, and carbon $(\mathrm{C})$, hydrogen $(\mathrm{H})$, sulfur $(\mathrm{S})$, and oxygen $(\mathrm{O})$ are the chemical elements obtained from the ultimate analysis.

\subsection{Determination of the Energy Potential and Electrical Power Potential of the MSW} 2.5.1. Determination of Energy Potentials $\left(E P_{m s w}\right)$ of the Municipal Solid Waste

Daura [39] and Ibikunle [10] reported that the energy potential (EP $m$ msw $)$ of MSW could be determined by applying Equation (6):

$$
E P_{m s w}=L H V_{m s w} \times w_{m s w} \times \frac{1000}{3.6}(\mathrm{kWh})
$$

where $E P_{m s w}$ is the energy potential from MSW, $W_{m s w}$ (tons) is the weight of MSW, $L H V_{m s w}$ is the net low heating value of the MSW $(\mathrm{MJ} / \mathrm{kg})$. Conversion ratio $(1 \mathrm{kWh}=3.6 \mathrm{MJ})$.

$$
E P_{\text {msw }}=20 \times 584 \times 227.7=3,244,444 \mathrm{kWh} \text { or } 3.2 \mathrm{GWh}
$$


2.5.2. Determination of the Electrical Power Potential $\left(E P P_{m s w}\right)$ of the Municipal Solid Waste

The Electrical Power Potential $\left(E P P_{m s w}\right)$ of the MSW Is Determined Using Equation (7) as Suggested by Ibikunle [7,10] and Daura [39]

$$
\begin{gathered}
E P P_{m s w}=277.8 \times L H V_{m s w} \times \frac{w_{m s w}}{24} \times \eta(\mathrm{kW}) \\
E P P_{m s w}=40,602 \mathrm{~kW}
\end{gathered}
$$

where $\eta$ is the conversion efficiency in a power plant, which is within a range of $20-40 \%$ as reported by Muhammad [40] and Ibikunle [7,10]. However, conversion efficiency of 30\% is adopted for this work.

$$
\begin{gathered}
\text { Power to grid }(G P)=E P P_{m s w} \times \eta_{\mathrm{g}} \times \eta_{\mathrm{p}} \times \frac{1}{1000}(\mathrm{MW}) \\
G P=27.3 \mathrm{MW}
\end{gathered}
$$

where $\eta_{\mathrm{g}}$ is the generator efficiency (selected is $90 \%$ ), $\eta_{\mathrm{p}}$ is the transmission efficiency (selected is $75 \%$ ) of turbine work $\left(W_{T}\right)$. The generator efficiency range is $85-90 \%$ and turbine efficiency is within a range of $75-80 \%$ [41].

\subsection{Determination of the Steam Power Plant Capacity Required for Energy Production}

Thermodynamic analysis of Rankine cycle is used to enhance the reliability and efficiency of steam power plants [42]. In this study, the reheat Rankine cycle presented in Figure $2 b$ is used to determine the capacity of the steam power plant that will convert the waste to electrical power. Rankine reheat cycle in Figure $2 b$ was used for the estimation of the steam power plant capacity because it has a higher cycle efficiency compared to the ordinary superheat Rankine cycle shown in Figure 2a. The combination of temperature $\left(400{ }^{\circ} \mathrm{C}\right.$ ) and pressure (40 bar) is commonly used in the capacity determination/design for steam power plants to minimize investment costs. Temperature higher than $400{ }^{\circ} \mathrm{C}$ may result in high-temperature strain and corrosion of the superheater tubes; also, the pressure below 40 bar lowers the requirements for pretreatment of the feed water $[7,43,44]$.

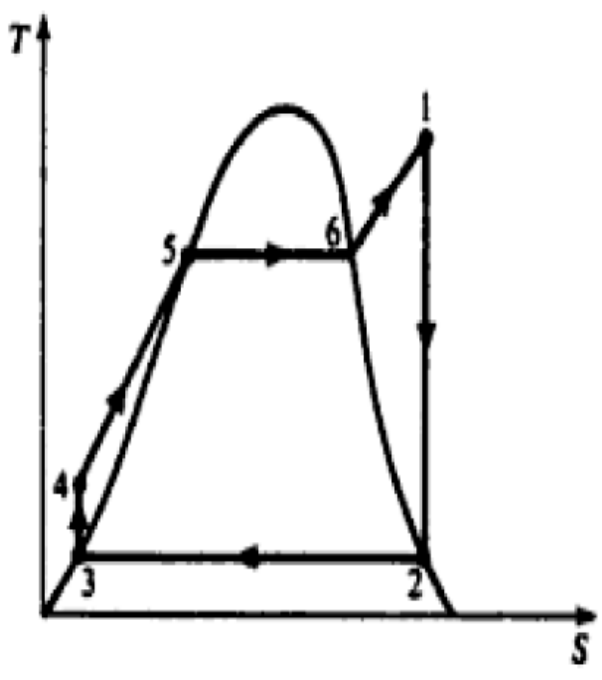

(a)

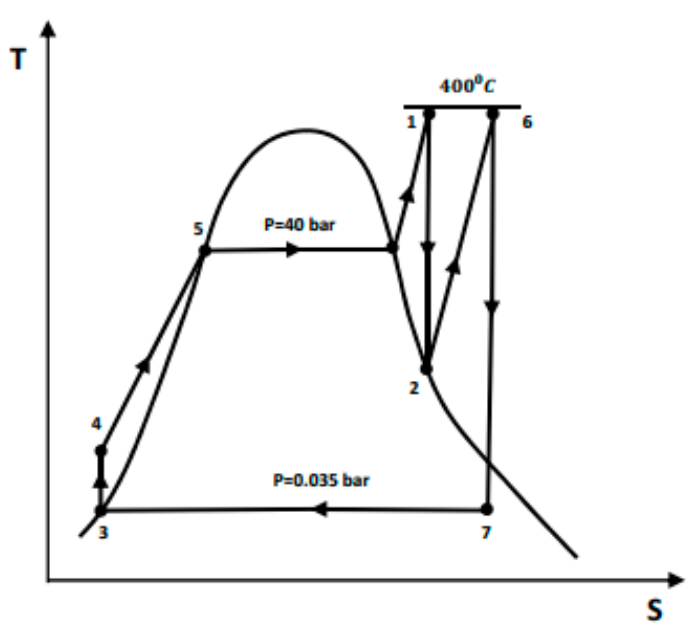

(b)

Figure 2. (a) T-S Rankine cycle with superheat; (b) T-S reheat Rankine cycle.

The reheat Rankine cycle in Figure $2 b$ is a modification of simple Rankine cycle in Figure 2a. The schematic representation of a steam power plant using the reheat Rankine cycle is shown in Figure 3. 


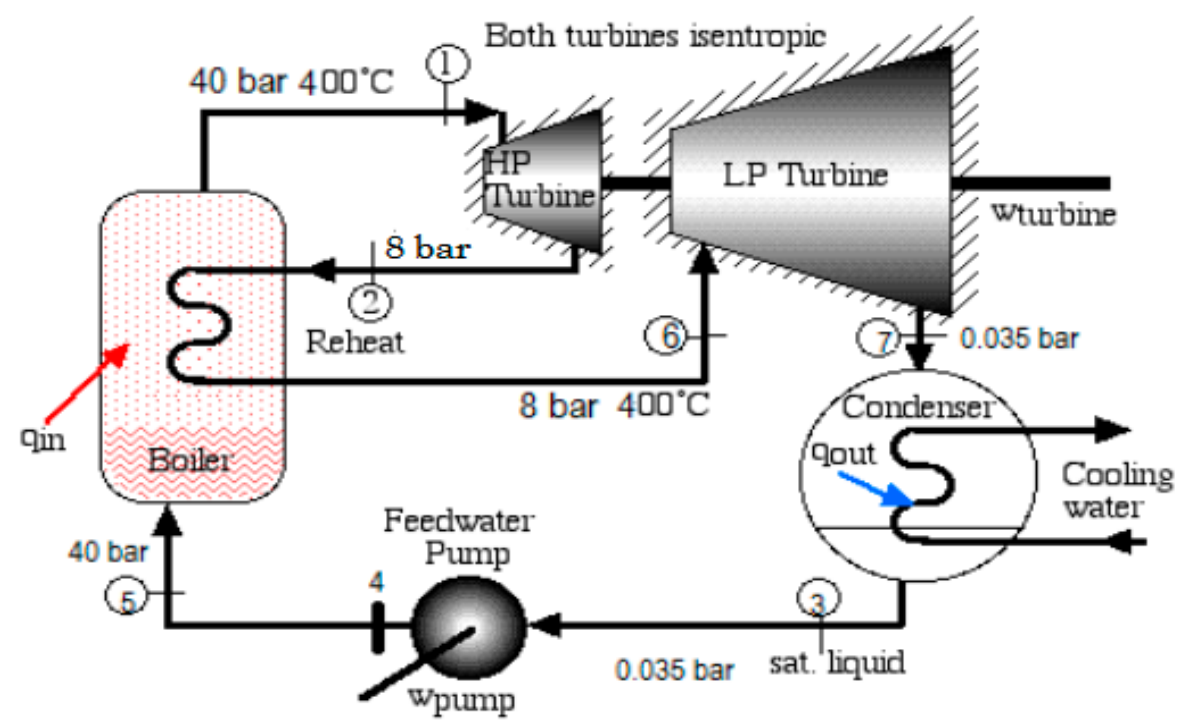

Figure 3. Rankine component layout of a steam power plant. Source: Karlsson and Jonsson [44].

Work Output $\left(W_{T_{12}}\right)$ of the High-Pressure Turbine (HPT) can Be Determined Using Equation (9), as Suggested by Kaspooria [42], Akhator [12], Arabkooshar [45], and Loni [46]

$$
\dot{W}_{T_{12}}=\dot{m}_{s t}\left(h_{1}-h_{2}\right)
$$

where, $W_{T_{12}}(\mathrm{~kJ} / \mathrm{kg})$ is the HPT work output, $\dot{m}_{s t}$ is the mass flow rate of the steam, $h_{1}$ and $h_{2}$ are the enthalpies at states 1 and 2 during the isentropic expansion process in the HPT.

According to Jordi [47] and Hesham [48], the Heat $\left(\mathrm{Q}_{26}\right)$ Supplied to the Steam at the Reheat Tube can be Determined Using Equation (10)

$$
\dot{Q}_{T_{26}}=\dot{m}_{s t}\left(h_{6}-h_{2}\right)
$$

where $\dot{Q}_{T_{26}}$ is the rate of heat supplied to the steam, during the constant pressure heating process, from state 2 to 6 in the reheat tube.

Work Output $\left(W_{T_{67}}\right)$ of the Low-Pressure Turbine (LPT) can Be Determined as Suggested in Equation (11), by Akhator [12] and Arabkooshar [45]

$$
\dot{W}_{T_{67}}=\dot{m}_{s t}\left(h_{6}-h_{7}\right)
$$

where $W_{T_{67}}(\mathrm{~kJ} / \mathrm{kg})$ is the LPT work output, and $h_{6}$ and $h_{7}$ are the enthalpies at states 6 and 7 of the reheat Rankine cycle, during the isentropic expansion process in the LPT.

Heat $\left(\dot{Q}_{73}\right)$ Rejected at the Condenser According to Akhator [12], Arabkooshar [45], and Loni [46] is Presented in Equation (12)

$$
\dot{Q}_{73}=\dot{m}_{s t}\left(h_{7}-h_{3}\right)
$$

where $\dot{Q}_{37}(\mathrm{~kJ} / \mathrm{kg})$ is the heat rejected in the condenser during an isothermal heat rejection process, while $h_{7}$ and $h_{3}$ are the enthalpies at states 7 and 3 of the reheat Rankine cycle respectively.

Heat $\left(\dot{Q}_{31}\right)$ Supplied to the Boiler can Be Determined in Equation (13), as Suggested by Eastop [49], Sadhu [50], Ting [51], and Ibikunle [7]

$$
\dot{Q}_{31}=\dot{m}_{s t}\left(h_{1}-h_{3}\right)
$$

where $\dot{Q}_{31}(\mathrm{~kJ} / \mathrm{Kg})$ is the heat supplied to the boiler, while $h_{1}$ and $h_{3}$ are the enthalpies at states 1 and 3 of the reheat Rankine cycle respectively. 
The Total Heat $\left(\mathrm{Q}_{\mathrm{B}}\right)$ Supplied by the Boiler to the Steam

$$
\mathrm{Q}_{\mathrm{B}}=\mathrm{Q}_{31}+\mathrm{Q}_{26}
$$

where $Q_{B}$ is the addition of heat $Q_{13}$ and the heat of reheat $Q_{26}$.

\subsubsection{The Cycle Efficiency $\left(\eta_{\mathrm{c}}\right)$}

According to Eastop [49], Sadhu [50], and Winterbone [52], the cycle efficiency is calculated using Equation (15):

$$
\text { Cycle efficiency } \eta_{\mathrm{c}}=\frac{\text { Work output }}{\text { Heat input }}=\frac{\left(W_{T_{12}}+W_{T_{67}}\right)}{\mathrm{Q}_{\mathrm{B}}}
$$

2.6.2. The Net Heat Supplied $\left(Q_{n e t}\right)$

It is calculated by adopting Equation (16), as suggested by Eastop [49] and Sadhu [50]:

$$
\text { Net heat supplied }\left(Q_{\text {net }}\right)=\left(Q_{B}-Q_{37}\right)
$$

Estimation of the Capacity for the Components of the Steam Power Plant in Equations (17)-(22) Is Suggested by Ibrahim [53], Ibikunle [7], and Oyedepo [54]

$$
\begin{gathered}
\text { Steam mass flow rate }\left(\dot{m}_{s t}\right)=\frac{\text { Capacity of Steam power plant }}{\text { Net heat supplied }}=\frac{E P P_{\text {msw }}}{Q_{\text {net }}} \\
\text { Specific steam consumption }(\mathrm{SSC})=\frac{3600}{W_{\text {net }}}(1 \mathrm{~kW}=3600 \mathrm{~kJ} / \mathrm{h})
\end{gathered}
$$

where net work $\left(W_{n e t}\right)$ is equal to net heat $\left(Q_{\text {net }}\right)$.

$$
\text { MSW consumption rate, } \dot{m}_{f}=\dot{m}_{s t}\left[\left(\left(h_{1}-h_{3}\right)+\left(h_{6}-h_{2}\right)\right) /(\eta B \times L H V)\right]
$$

where $m_{f}$ is taken as the rate of fuel consumption, the boiler efficiency is $\eta_{\mathrm{B}}$, and the low heating value of MSW is LHV. Efficiency of $80 \%$ is assumed for the boiler (the range of boiler efficiency is $80-90 \%$ ) [38].

$$
\text { Boiler power }\left(Q_{B P}\right) \text { : The boiler power, } \mathrm{Q}_{\mathrm{BP}}=\dot{\mathrm{m}}_{\mathrm{st}} \times \mathrm{Q}_{\mathrm{B}}
$$

where $\mathrm{Q}_{\mathrm{BP}}$ is considered as the power generated/day by the boiler for steam power plant.

$$
\text { The turbine power output }\left(\mathrm{P}_{\mathrm{T}}\right)=\dot{\mathrm{m}}_{\mathrm{st}} \times \mathrm{W}_{\mathrm{T}}
$$

The total work output of the turbine,

$$
\begin{gathered}
\mathrm{W}_{\mathrm{T}}=\left(W_{T_{12}}+W_{T_{67}}\right) \\
\text { The Condenser Power }\left(\mathrm{Q}_{\mathrm{PC}}\right)=\dot{\mathrm{m}}_{\mathrm{st}} \times \mathrm{Q}_{73}
\end{gathered}
$$

\subsection{Development of Software for Selecting Power Plant Capacity}

The nomenclature of all the parameters used in modeling the energy and electrical potentials of MSW, and the parameters used in modeling the power plant capacity required were prepared. An algorithm based on Equations (2)-(19) was prepared, which was translated into computer soft code using Java programming language (which is one of the common languages used in numerical analysis and a unified modeling language) [25]. The flow chart upon which the algorithm is based is shown in Figure 4. The software interface was developed using Java swing utilities which comprise mostly of JFrames, JTextrafields, JButtons, and JEditorpane for data display. Action listeners and action events were used to control the button functionalities, handle calculations, and panel/Editorpane displays. Java was used due to its flexibility, object-oriented programming language, and 
its multi-platform capabilities, which allows it to function on any operating system (OS). The conversion ratios for MSW in tons to kilograms, the heating value in $\mathrm{MJ} / \mathrm{kg}$ to energy potential in $\mathrm{kWh}$, the saturated and superheated water tables, and steam properties were incorporated into the software's database [25].

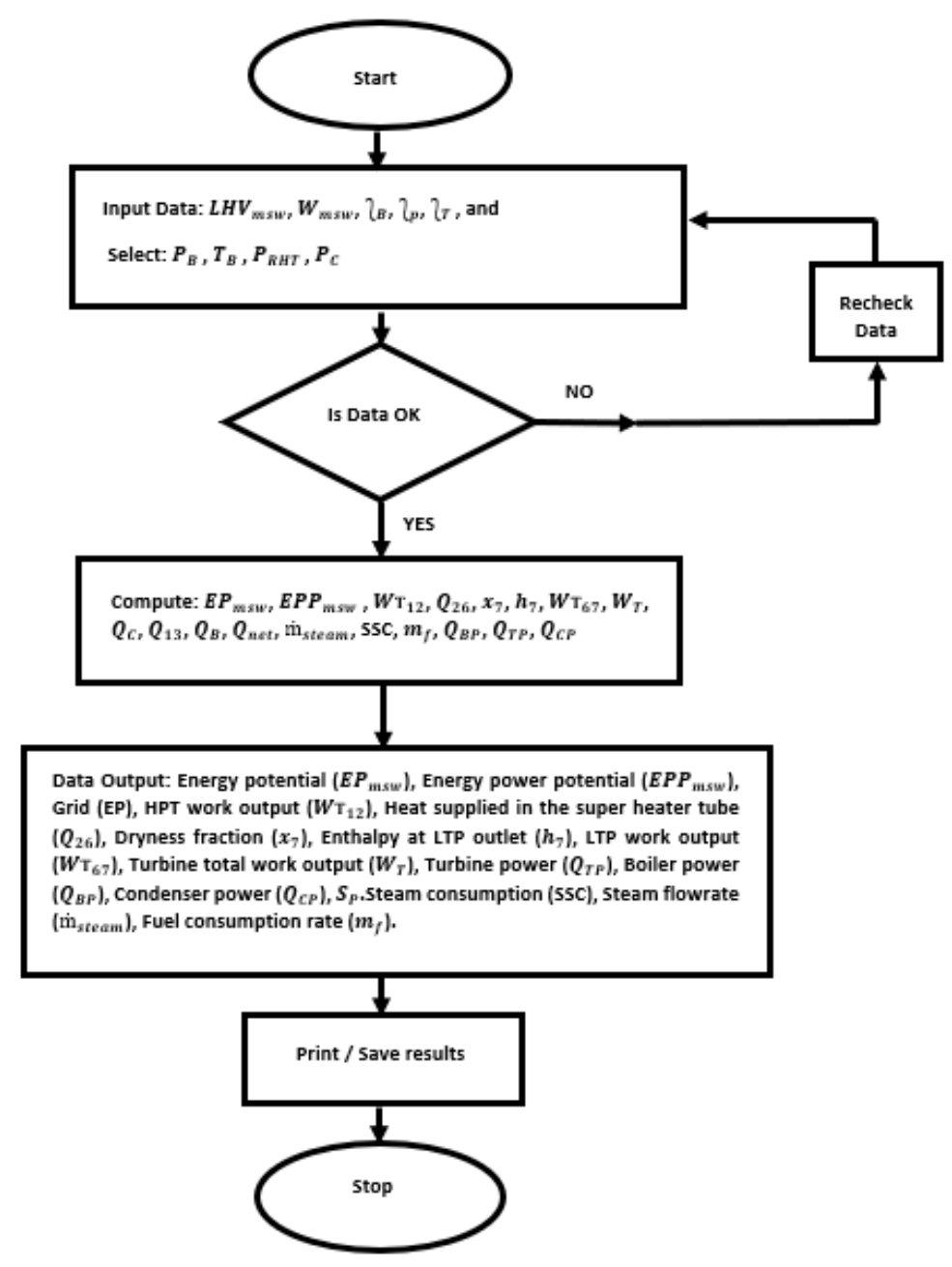

Figure 4. Flowchart of decision support system for steam power plant capacity.

The Flowchart for the Decision Support System

1. The weight of MSW available for energy generation, heating value of the MSW, boiler efficiency, conversion efficiency, and turbine efficiency was supplied into the corresponding designated box in the input interface shown in Figure 5,

2. The boiler pressure, boiler temperature, pressure in the reheat tube, and the pressure required in the condenser are selected from the corresponding draw-down of the icons provided in the input interface,

3. After the required parameters have been supplied/selected; the system requests that you proceed, and the proceed button is clicked,

4. Then, a verification interface, shown in Figure 6, will appear to ask if data is OKAY; if $\mathrm{OK}$, click on proceed button otherwise click on the recheck data button and continue,

5. Then click on the process button, and it will automatically process the data. After that, click on proceed button and the result will automatically be displayed on an output interface, as well as the date and exact time of processing as presented in Figure 7. 


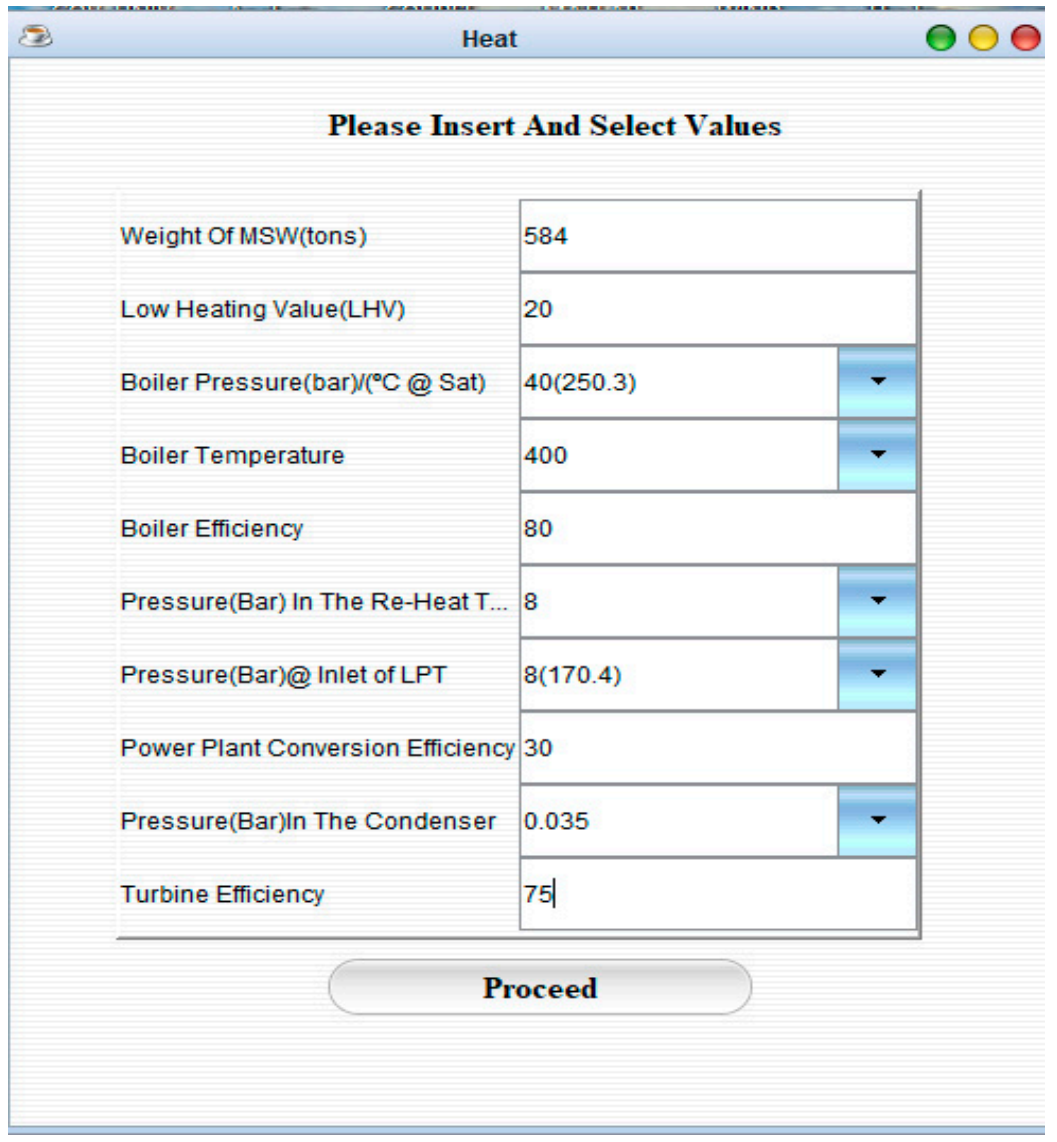

Figure 5. The input interface of the software to predict the capacity of the steam power plant.

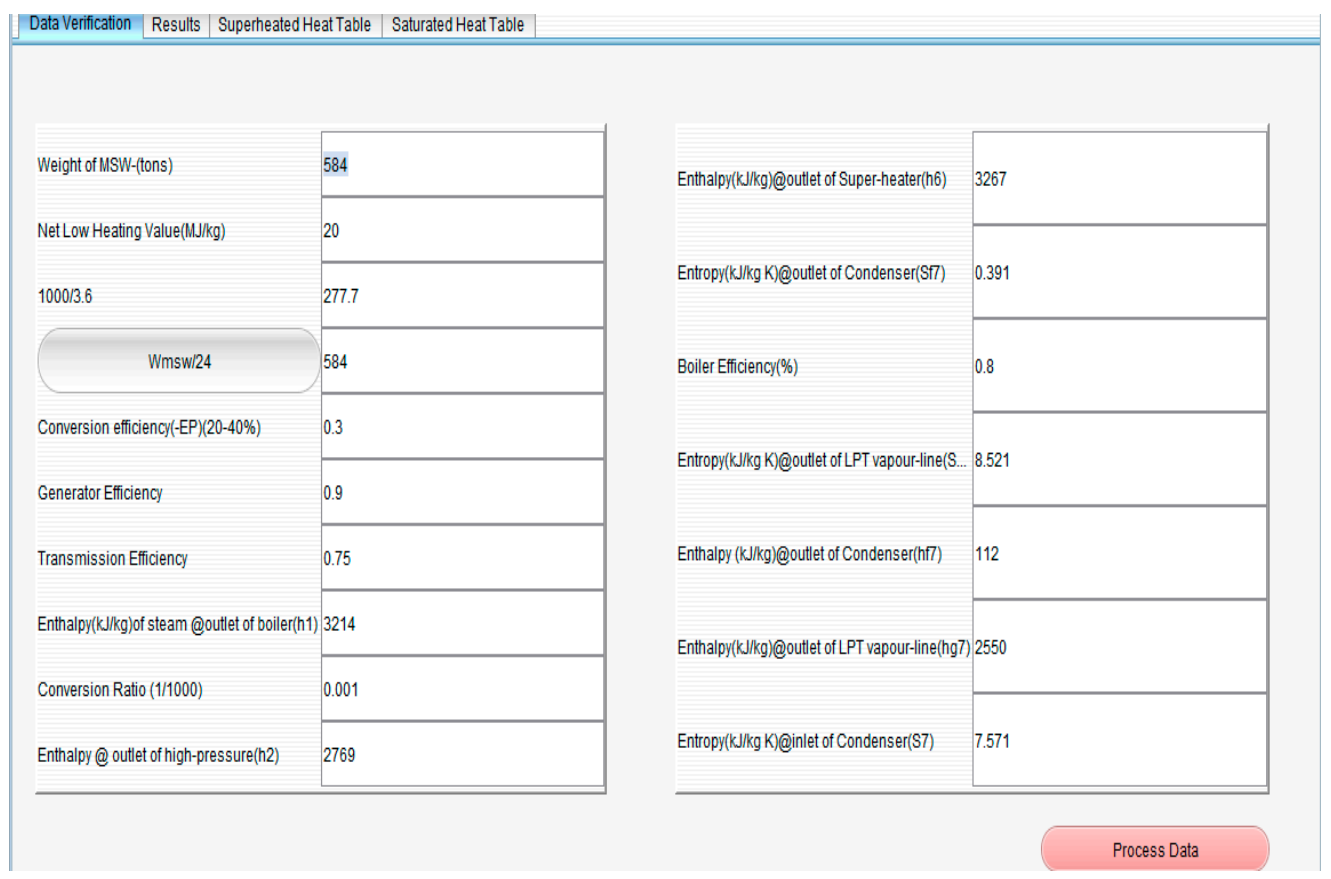

Figure 6. The verification interface of the software to recheck for the missing data. 


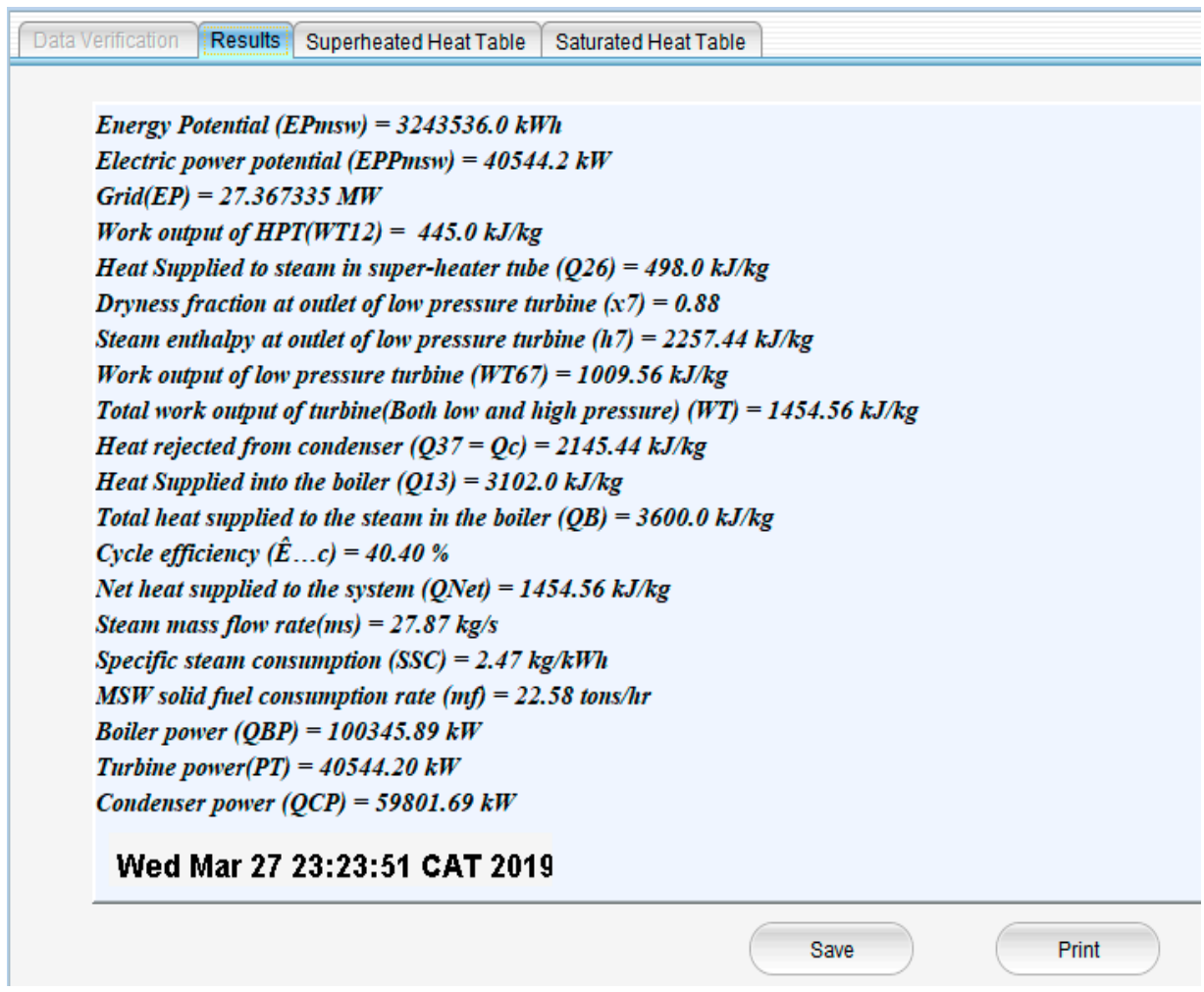

Figure 7. The values generated from the data processed by the software.

The results displayed include appropriate energy and electrical power potentials of the MSW, the work-output of the high-pressure and the low-pressure turbines, the heat rejected at the condenser, the heat supplied in the boiler, the boiler power, the turbine power, the condenser power required to convert the quantity of MSW to power, and the enthalpies at the different nodes of the reheat Rankine cycle.

\section{Results and Discussion}

In this section, the aggregate of the MSW produced in the Ilorin metropolis, the components in the MSW streams, their energy content, and the capacity of the waste-fired power plant required for electricity generation is established. Moreover, the manuallycalculated values and the values generated by the selection support system are compared. These include the heat energy, electrical power potentials of a quantity of MSW, energy at the thermodynamic states of the Rankine cycle, and the required capacity of the power plant that will convert the MSW; this is to ascertain the accuracy of the decision support system.

\subsection{The Estimated Aggregate of MSW Produced}

The quantity of MSW generated in a city must be considered to be able to estimate the quantity of the fractions that are suitable for energy production. The MSW generated in Ilorin between January and June 2021, as presented in Table 1, was predicted to be about 101,912 tons, based on the facts and the figures of the waste collection system without the use of a weighing machine, compared to 370,706 tons/year generated in Onitsha (the eastern part of Nigeria) and 10,000 tons of MSW/day in Lagos, the commercial center of Nigeria [55], 250 tons of MSW/year in Ado-Ekiti (Western Nigeria) [56], 30 million tons/year in the US [57], 2.15 million tons/year in Sweden [58], 46 million in China [59], and 169,120 tons of MSW / day in Africa [60]. The aggregate waste produced during this study implies that the MSW generated in Ilorin is sufficient for the renewable energy process. The quantity collected for disposal was estimated, as suggested by Ogunjuyigbe [13], that 
the aggregate of MSW collected and disposed of in most of the developing nations is about $74 \%$ of the quantity generated.

Table 1. Estimation of MSW generated in Ilorin during the study based on transportation facts.

\begin{tabular}{ccccccc}
\hline $\begin{array}{c}\text { Collection } \\
\text { Trucks }\end{array}$ & $\begin{array}{c}\text { Trucks Used } \\
\text { Per Day }\end{array}$ & $\begin{array}{c}\text { Capacity } \\
\text { (Tons) }\end{array}$ & $\begin{array}{c}\text { Capacity } \\
\mathbf{( m}^{\mathbf{3}}\end{array}$ & $\begin{array}{c}\text { Trips of } \\
\text { Truck/Day }\end{array}$ & $\begin{array}{c}\text { MSW Collected } \\
\text { (Tons) }\end{array}$ & $\begin{array}{c}\text { MSW Generated } \\
\text { (Tons) }\end{array}$ \\
\hline Dinno Tipper Truck & 5 & 20 & 16 & 3 & $26,006.25$ & $35,143.5$ \\
Hippo Tipper Truck & 3 & 25 & 22 & 3 & $19,498.5$ & 26,349 \\
Scannia Compactor & 2 & 30 & 22 & 2 & $10,405.5$ & 14,061 \\
Arm Roller & 3 & 15 & 8 & 5 & $19,504.5$ & 26,358 \\
Total & 13 & 90 & 68 & 13 & $75,414.75$ & $101,911.5$ \\
\hline
\end{tabular}

\subsection{The Physical Characterization of the MSW Components}

Table 2 reveals that the quantity of MSW characterized during the study is about $985 \mathrm{~kg}$. The population responsible for MSW generation during this study is 1,222,294 people as predicted by Ibikunle [5]. The aggregate waste characterized during June is about $229 \mathrm{~kg}$, followed by $182 \mathrm{~kg}$ in May, and the least is about $156 \mathrm{~kg}$ in February. The reason for June having the highest quantity of MSW of about $23 \%$ of the total waste characterized, might be because during this period, newly harvested crops are emerging from farm and food items, and others are cheaper, making it affordable for many people than before. February had the least waste, which might be due to the dry season when there was no plant nor harvesting of food crops and people have just concluded the new year celebration and did not have enough money to purchase items. In this characterization study, plastic bottles have the highest fraction of about $13 \%$, followed by grass/garden trimmings of about $8 \%$, and leather having the least of about $1 \%$. The reason for the high fraction of plastic bottles is because many people consume bottled water and other drinks. Leather has the lowest fraction because it is treasured for ornamental crafts, bags, and shoes in Ilorin, hence it is rare to come by its waste fractions. The generation rate of MSW during this study is $0.145 \mathrm{~kg} /$ capita/day.

Table 2. Physical characterization of MSW components (of $985 \mathrm{~kg}$ ) for six months (January to February).

\begin{tabular}{ccccccccccc}
\hline \multirow{2}{*}{ MSW Components } & Jan. & Feb. & March & April & May & June & Total & Wt. & Kg/Capita \\
\cline { 2 - 7 } & Wt. (kg) & Wt. (kg) & Wt. (kg) & Wt. (kg) & Wt. (kg) & Wt. (kg) & Wt. (kg) & \% & /Day \\
\hline Food residue & 12.25 & 10.00 & 8.35 & 8.00 & 14.21 & 26.35 & 79.16 & 8.04 & 0.012 \\
Wood & 4.65 & 4.85 & 4.25 & 3.85 & 3.25 & 2.45 & 23.30 & 2.37 & 0.003 \\
Paper & 8.80 & 6.50 & 6.20 & 4.60 & 8.35 & 6.55 & 41.00 & 4.16 & 0.006 \\
Packaging box & 14.24 & 18.55 & 12.50 & 7.80 & 10.55 & 12.20 & 75.84 & 7.70 & 0.011 \\
Grass/trimmings & 3.64 & 8.20 & 10.60 & 12.40 & 21.12 & 24.22 & 80.18 & 8.14 & 0.012 \\
Textiles (rags) & 4.20 & 6.22 & 8.46 & 10.20 & 10.25 & 14.24 & 53.57 & 5.44 & 0.008 \\
Toiletries & 3.40 & 4.56 & 2.28 & 1.12 & 0.84 & 3.18 & 15.38 & 1.56 & 0.002 \\
Feces & 1.64 & 4.62 & 2.08 & 5.10 & 8.24 & 10.32 & 32.00 & 3.25 & 0.005 \\
Cow dung & 8.45 & 6.45 & 5.45 & 3.35 & 4.42 & 4.45 & 32.57 & 3.31 & 0.005 \\
Nylon (water sachet) & 18.00 & 16.24 & 10.24 & 8.46 & 6.45 & 8.22 & 67.61 & 6.87 & 0.010 \\
Polypropylene sack & 12.20 & 8.42 & 6.20 & 8.20 & 10.55 & 20.14 & 65.71 & 6.67 & 0.010 \\
Plastic bottle & 30.25 & 22.00 & 20.68 & 14.24 & 18.24 & 20.12 & 125.53 & 12.75 & 0.018 \\
Rubber & 0.82 & 1.20 & 1.22 & 0.14 & 5.20 & 5.24 & 13.82 & 1.40 & 0.002 \\
Leather & 0.64 & 0.26 & 1.20 & 0.22 & 4.10 & 4.16 & 10.58 & 1.07 & 0.002 \\
Glass/Ceramics & 10.40 & 9.80 & 10.40 & 6.00 & 10.12 & 9.85 & 56.57 & 5.74 & 0.008 \\
Animal bones & 2.64 & 1.12 & 0.80 & 2.45 & 10.22 & 12.25 & 29.48 & 2.99 & 0.004 \\
Tins/Metals & 12.00 & 10.00 & 14.00 & 8.20 & 6.35 & 14.66 & 65.21 & 6.62 & 0.010 \\
Sand/Ash & 10.90 & 8.80 & 6.30 & 4.30 & 5.12 & 4.62 & 40.04 & 4.07 & 0.006 \\
Other biogenic & 6.24 & 8.64 & 5.40 & 6.80 & 24.54 & 25.52 & 77.14 & 7.83 & 0.011 \\
Grand total & 165.36 & 156.43 & 136.61 & 115.43 & 182.12 & 228.74 & 984.69 & 100.00 & 0.145 \\
\hline
\end{tabular}




\subsection{The Combustible MSW Fractions That Are Considered for Energy Production}

Nine combustible fractions of the 19 MSW components that were characterized are considered for energy production, as presented in Table 3. The table shows that about $612 \mathrm{~kg}$ of combustible waste fractions were characterized during this study. This makes about $62 \%$ of the waste generated. This implies about 63,185 tons of combustible MSW were available for energy production during the investigation. Ibikunle et al. (2019) estimated the combustible components of MSW in Ilorin for the year 2016 to be about 71\%, compared to $84 \%$ in Ghana in 1983 and $27 \%$ in 2014; $7.7 \%$ in South Africa; $74 \%$ in Nigeria, and $3.6 \%$ of the US [61]. This implies energy recovery from MSW via combustion in 2016 will reduce the quantity of waste deposited into the dumpsite in Ilorin metropolis by about $71 \%$, but this recent study revealed that energy recovery via combustion of waste fractions could reduce the aggregate waste deposited into the dumpsite in Ilorin by about $62 \%$ within six months.

Table 3. Physical characterization of MSW (of $612 \mathrm{~kg}$ ) for energy production between January-February.

\begin{tabular}{|c|c|c|c|c|c|c|c|c|}
\hline \multirow{2}{*}{ MSW Components } & Jan. & Feb. & March & April & May & June & Total & Wt. \\
\hline & Wt. (kg) & Wt. (kg) & Wt. (kg) & Wt. (kg) & Wt. (kg) & Wt. (kg) & Wt. (kg) & $\%$ \\
\hline Food residue & 12.25 & 10.00 & 8.35 & 8.00 & 14.21 & 26.35 & 79.16 & 8.04 \\
\hline Wood & 4.65 & 4.85 & 4.25 & 3.85 & 3.25 & 2.45 & 23.30 & 2.37 \\
\hline Paper & 8.80 & 6.50 & 6.20 & 4.60 & 8.35 & 6.55 & 41.00 & 4.16 \\
\hline Packaging box & 14.24 & 18.55 & 12.50 & 7.80 & 10.55 & 12.20 & 75.84 & 7.70 \\
\hline Grass/garden trimmings & 3.64 & 8.20 & 10.60 & 12.40 & 21.12 & 24.22 & 80.18 & 8.14 \\
\hline Textiles (rags) & 4.20 & 6.22 & 8.46 & 10.20 & 10.25 & 14.24 & 53.57 & 5.44 \\
\hline Nylon (water sachet) & 18.00 & 16.24 & 10.24 & 8.46 & 6.45 & 8.22 & 67.61 & 6.87 \\
\hline Polypropylene sack & 12.20 & 8.42 & 6.20 & 8.20 & 10.55 & 20.14 & 65.71 & 6.67 \\
\hline Plastic bottle & 30.25 & 22.00 & 20.68 & 14.24 & 18.24 & 20.12 & 125.53 & 12.75 \\
\hline Total & 108.23 & 100.98 & 87.48 & 77.75 & 102.97 & 134.49 & 611.90 & 62.14 \\
\hline
\end{tabular}

\subsection{The Thermochemical Analysis of Combustible MSW Components}

Table 4 presents the ultimate analysis of the waste fractions and the high heating value (HHV) of the components obtained from the bomb calorimeter. The analyses reveal that the average elemental components of the waste fractions give $29.14 \%$ composition of carbon, $0.11 \%$ of hydrogen, $3.95 \%$ of nitrogen, $0.50 \%$ of sulfur, and $0.15 \%$ of oxygen. The average HHV of the MSW components is $25 \mathrm{MJ} / \mathrm{kg}$. These values are very important in the estimation of the energy and power potentials of MSW.

Table 4. Thermochemical analysis of MSW components.

\begin{tabular}{ccccccc}
\hline MSW Fractions & $\mathbf{C} \%$ & $\mathbf{H} \%$ & $\mathbf{N} \%$ & $\mathbf{S} \%$ & $\mathbf{O} \%$ & HHV $(\mathbf{M J} / \mathbf{k g})$ \\
\hline Food residue & $37.88 \pm 0.44$ & $0.17 \pm 0.00$ & $4.68 \pm 0.05$ & $3.80 \pm 0.02$ & $0.16 \pm 0.00$ & 18.56 \\
Wood & $36.80 \pm 0.62$ & $0.11 \pm 0.02$ & $4.46 \pm 0.04$ & $0.06 \pm 0.02$ & $0.08 \pm 0.00$ & 18.38 \\
Paper & $34.68 \pm 0.08$ & $0.08 \pm 0.02$ & $4.58 \pm 0.24$ & $0.10 \pm 0.00$ & $0.07 \pm 0.00$ & 17.28 \\
Packaging box & $21.45 \pm 0.06$ & $0.11 \pm 0.00$ & $3.32 \pm 0.10$ & $0.08 \pm 0.03$ & $0.12 \pm 0.00$ & 16.68 \\
Grass /garden trimmings & $31.46 \pm 0.11$ & $0.09 \pm 0.02$ & $3.81 \pm 0.06$ & $0.07 \pm 0.00$ & $0.06 \pm 0.00$ & 17.78 \\
Textiles (rags) & $33.66 \pm 0.14$ & $0.10 \pm 0.00$ & $4.26 \pm 0.00$ & $0.14 \pm 0.00$ & $0.15 \pm 0.00$ & 16.45 \\
Nylon & $21.86 \pm 0.08$ & $0.11 \pm 0.00$ & $3.56 \pm 0.02$ & $0.13 \pm 0.00$ & $0.08 \pm 0.00$ & 45.26 \\
Polypropylene sack & $21.65 \pm 0.11$ & $0.11 \pm 0.02$ & $3.42 \pm 0.01$ & $0.06 \pm 0.00$ & $0.06 \pm 0.00$ & 38.88 \\
Plastic bottle & $22.84 \pm 0.03$ & $0.10 \pm 0.00$ & $3.43 \pm 0.00$ & $0.08 \pm 0.02$ & $0.11 \pm 0.02$ & 36.86 \\
\hline
\end{tabular}

The low heating value (LHV) of the waste components that is paramount in the estimation of power potential as determined by adopting Dulong and Steuer models in Equations (3) and (4) is presented in Table 5a. The average HHV from the bomb calorimeter is $25 \mathrm{MJ} / \mathrm{kg}$, the average $\mathrm{LHV}^{\mathrm{b}}$ from the Dulong model is about $21 \mathrm{MJ} / \mathrm{kg}$, and $\mathrm{LHV}^{\mathrm{c}}$ from the Steuer model is about $20.8 \mathrm{MJ} / \mathrm{kg}$. Moreover, the LHV obtained from Equation (2) is about $19 \mathrm{MJ} / \mathrm{kg}$. Therefore, considering the results from the three equations, the typical 
value for the LHV is assumed to be $20 \mathrm{MJ} / \mathrm{kg}$. The MSW with LHV of $20 \mathrm{MJ} / \mathrm{kg}$ will produce correspondent energy of about $43 \%$ of petrol, $45 \%$ of energy in diesel, $48 \%$ of that in natural gas, $49 \%$ in coal, and about $100 \%$ of energy content in woody biomass [62].

Table 5. (a) The LHV of the MSW components from Dulong and Steuer models; (b) Energy potential $\left(E P_{M S W}\right)$ and electrical power potential $\left(E P P_{M S W}\right)$ of MSW.

\begin{tabular}{|c|c|c|c|c|c|}
\hline \multicolumn{6}{|c|}{ (a) } \\
\hline MSW Fractions & $\begin{array}{c}\mathrm{HHV} \\
(\mathrm{MJ} / \mathrm{kg})\end{array}$ & $\mathrm{HV} \%$ & $\begin{array}{l}\mathrm{LHV}^{\mathrm{b}} \\
(\mathrm{MJ} / \mathrm{kg})\end{array}$ & $\begin{array}{l}\mathrm{LHV}^{\mathrm{c}} \\
(\mathrm{MJ} / \mathrm{kg})\end{array}$ & $\begin{array}{l}\text { Typical LHV } \\
(\mathrm{MJ} / \mathrm{kg})\end{array}$ \\
\hline Food residue & 18.56 & 8.21 & 27.20 & 26.50 & 26.85 \\
\hline Wood & 18.38 & 8.13 & 24.12 & 24.31 & 24.22 \\
\hline Paper & 17.28 & 7.64 & 26.03 & 26.00 & 26.02 \\
\hline Packaging box & 16.68 & 7.38 & 16.01 & 16.01 & 16.01 \\
\hline $\begin{array}{l}\text { Grass/garden } \\
\text { trimmings }\end{array}$ & 17.78 & 7.86 & 21.03 & 21.51 & 21.27 \\
\hline Textiles (rags) & 16.45 & 7.27 & 24.21 & 23.34 & 23.78 \\
\hline Nylon & 45.26 & 20.02 & 17.02 & 18.10 & 17.56 \\
\hline Polypropylene sack & 38.88 & 17.19 & 15.25 & 17.02 & 16.14 \\
\hline Plastic bottle & 36.86 & 16.30 & 15.16 & 17.00 & 16.08 \\
\hline Total & 226.13 & 100 & 186.03 & 189.79 & 187.91 \\
\hline Average & 25 & & 20.67 & 21.09 & 20.88 \\
\hline \multicolumn{6}{|c|}{ (b) } \\
\hline Types & \multicolumn{2}{|c|}{ MSW (tons)/day } & $\begin{array}{c}\mathrm{LHV} \\
(\mathrm{MJ} / \mathrm{kg})\end{array}$ & $\begin{array}{c}E P_{M S W} \\
(\mathrm{kWh})\end{array}$ & $E P P_{M S W}(\mathrm{~kW})$ \\
\hline Food residue & \multicolumn{2}{|c|}{85.75} & 1.93 & 263,067 & 3288.34 \\
\hline Wood & \multicolumn{2}{|c|}{6.62} & 0.15 & 265,084 & 3313.55 \\
\hline Paper & \multicolumn{2}{|c|}{49.95} & 1.03 & 244,915 & 3061.44 \\
\hline Packaging box & \multicolumn{2}{|c|}{80.14} & 1.54 & 229,067 & 2863.34 \\
\hline $\begin{array}{l}\text { Grass/garden } \\
\text { trimmings }\end{array}$ & \multicolumn{2}{|c|}{36.97} & 0.80 & 256,440 & 3205.50 \\
\hline Textiles (rags) & \multicolumn{2}{|c|}{73.69} & 1.40 & 226,186 & 2827.33 \\
\hline Nylon & \multicolumn{2}{|c|}{125.95} & 7.03 & 665,592 & 8319.90 \\
\hline Polypropylene sack & \multicolumn{2}{|c|}{43.99} & 2.09 & 561,863 & 7023.29 \\
\hline Plastic bottle & \multicolumn{2}{|c|}{80.96} & 3.65 & 535,931 & 6699.14 \\
\hline Total & \multicolumn{2}{|c|}{584} & 20 & $3,248,145$ & $40,601.83$ \\
\hline
\end{tabular}

HHV: the high heating value from calorimetry experiment; LHV $^{\text {b }}$ t the low heating value from Dulong model $\mathrm{LHV}^{\mathrm{c}}$ : the low heating value from Steuer model, and Typical LHV: the average of the values from the models.

\subsection{The Energy Potential ( $\left.E P_{M S W}\right)$ and Electrical Power Potential of $M S W\left(E P P_{M S W}\right)$}

The methodology established that about $62 \%$ of the MSW characterized are combustible, therefore, considering about 584 tons out of about 63,185 tons of (combustible) waste fractions available during the study, with the low heating value (LHV) of $20 \mathrm{MJ} / \mathrm{kg}$, it can produce heat energy potential of $3.2 \mathrm{GWh}$ and electrical power potential of $40.6 \mathrm{MW}$ in a day, as presented in Table $5 \mathrm{~b}$. The available energy potential ( $\left.E P_{M S W}\right)$ of $3.2 \mathrm{GWh}$ in MSW will produce equivalent energy in 603 tons of wood, 395 tons of coal, 94 tons of hydrogen, $352,591 \mathrm{~L}$ of petrol, and 320,000 $\mathrm{L}$ of diesel [63]. The electrical power potential (EPP $\left.P_{M S W}\right)$ of the MSW is about $41 \mathrm{MW}$, and this will meet about $15 \%$ of the power requirement in Kwara State [64], as well as will help achieve about 9\% of the Nigeria Renewable Energy Master Plan (REMP) goal for 2025.

\subsection{The Capacity of the Steam Power Plant Components Required to Convert the MSW}

The capacities of the steam power plant components that will convert the available combustible MSW in Ilorin to energy were determined. It is established that a steam power plant output of $41 \mathrm{MW}$, operating on a reheat Rankine cycle of $40 \%$ efficiency, based on design specifications which operate in steam pressure and temperature of 40 bar and $400{ }^{\circ} \mathrm{C}$ respectively is required. Temperature higher than $400{ }^{\circ} \mathrm{C}$ can bring about high-temperature 
strain and corrosion in the boiler superheater tubes, and pressure below 40 bar can lower the requirements for pretreatment of the feed water [27,44,45]. The plant has an MSW fuel consumption rate of 40 tons $/ \mathrm{h}$, boiler capacity of $3600 \mathrm{~kJ} / \mathrm{kg}$ (heat input), turbine output capacity of $1455 \mathrm{~kJ} / \mathrm{kg}$ of steam, steam mass flow rate of $28 \mathrm{~kg} / \mathrm{s}$ (100 tons/h), and specific steam consumption (SSC) of $2.48 \mathrm{~kg} / \mathrm{kWh}$.

\subsection{The Thermodynamic Properties at each State in the Power Plant Cycle and the Capacities of the Power Plant Components}

The parameters determined for each node (state) during the thermodynamic processes required in the steam power generating procedures are given in Table 6a. The energy balance of the processes is given in Table $6 \mathrm{~b}$ and the capacities for each equipment of the power plant required are given in Table $6 \mathrm{c}$. Table $6 \mathrm{a}, \mathrm{b}$ contain pressures and temperatures selected from the steam table incorporated into the power plant design calculations to determine the enthalpy, entropy, work done, and the heat produced in different nodes of thermodynamic stages.

Table 6. (a) The parameters determined for the nodes of the steam power plant cycle; (b) The work done and the heat produced during the Rankine processes; (c) The capacities designed for the steam boiler power plant components.

\begin{tabular}{|c|c|c|c|c|c|}
\hline \multicolumn{6}{|c|}{ (a) } \\
\hline Description & \multicolumn{2}{|c|}{ Node Pressure (bar) } & \multirow{2}{*}{$\frac{\text { Temperature }\left({ }^{\circ} \mathrm{C}\right)}{400}$} & \multirow{2}{*}{$\begin{array}{c}\begin{array}{c}\text { Enthalpy } \\
(\mathrm{kJ} / \mathrm{kg})\end{array} \\
3214\end{array}$} & \multirow{2}{*}{$\begin{array}{c}\begin{array}{c}\text { Entropy } \\
(\mathrm{kJ} / \mathrm{kg} \mathrm{K})\end{array} \\
6.769\end{array}$} \\
\hline Boiler outlet/H-P turbine inlet & 1 & 40 & & & \\
\hline H-P turbine outlet/intermediate superheater inlet & 2 & 8 & 170.42 & 2769 & 6.663 \\
\hline Intermediate superheater outlet/L-P turbine inlet & 6 & 8 & 400 & 3267 & 7.571 \\
\hline L-P turbine outlet/condenser inlet & 7 & 0.035 & 26.7 & 2257.44 & 7.571 \\
\hline Condenser outlet/pump inlet & 3 & 0.035 & 26.7 & 112 & 0.391 \\
\hline Pump outlet/boiler inlet & 4 & 40 & 205 & 875 & 2.382 \\
\hline \multicolumn{6}{|c|}{ (b) } \\
\hline Work done & $\mathrm{kJ} / \mathrm{kg}$ & \multicolumn{3}{|c|}{ Heat } & $\mathrm{kJ} / \mathrm{kg}$ \\
\hline H-P turbine $\left(W T_{12}\right)$ & 445 & \multirow{4}{*}{\multicolumn{3}{|c|}{$\begin{array}{c}\text { Heat supplied into boiler }\left(Q_{13}\right) \\
\text { Heat supplied during reheat }\left(Q_{26}\right) \\
\text { Heat rejected from condenser }\left(Q_{37}\right) \\
\text { Net heat supplied }\left(Q_{n e t}\right)\end{array}$}} & 498 \\
\hline L-P turbine $\left(W T_{67}\right)$ & 1010 & & & & 498 \\
\hline Total work output of turbine (WT) & 1455 & & & & 2145 \\
\hline Net work done $\left(W_{n e t}\right)$ & 1455 & & & & 1455 \\
\hline \multicolumn{6}{|c|}{ (c) } \\
\hline \multicolumn{3}{|l|}{ Equipment } & Heat $(\mathrm{kJ} / \mathrm{kg})$ & Work $(\mathrm{kJ} / \mathrm{kg})$ & Power (MW) \\
\hline \multicolumn{3}{|l|}{ Boiler } & 3600 & - & 101 \\
\hline \multicolumn{3}{|l|}{ Turbine } & - & 1455 & 41 \\
\hline \multicolumn{3}{|l|}{ Condenser } & 2145 & - & 60 \\
\hline \multicolumn{6}{|c|}{ Steam and Fuel Consumption Rate of The Plant } \\
\hline & $\mathrm{kg} / \mathrm{s}$ & (tons $/ \mathrm{h}$ ) & $(\mathrm{kg} / \mathrm{kWh})$ \\
\hline \multicolumn{3}{|l|}{ Steam mass flow rate $\left(\dot{m}_{S}\right)$} & 27.87 & 100 & \\
\hline \multicolumn{3}{|l|}{ Fuel consumption rate $\left(m_{f}\right)$} & 6.25 & 22.58 & \\
\hline \multicolumn{3}{|l|}{ Specific steam consumption (SSC) } & & & 2.48 \\
\hline
\end{tabular}

Table $6 \mathrm{c}$ presents the heat, work, and power estimated for boiler, turbine, and condenser discretely, while determining the capacity of the power plant that will convert 584 tons of MSW to energy. This agrees with 'ZGB' (a manufacturer of boilers in China) with a rating range of 101-150 tons/h steam mass flow rate for boiler with the power of 70-105 MW.

\subsection{Software-Generated Values on Power Potential and Power Plant Capacity}

The software developed serves as the supporting tool for the selection of waste-toenergy (WTE) power plant capacity that will utilize MSW as fuel. This system determines 
the energy and power potentials of MSW when the known weight of MSW in tons and its low heating value $(\mathrm{MJ} / \mathrm{kg})$ are inputted into the input interface of the software shown in Figure 5. The data inputted are verified in the interface in Figure 6, to ensure errorfree processes, before the data is processed. The results obtained using the software are presented in output display Figure 7. This decision support system will predict the capacity of the power plant required for energy recovery of any quantity of MSW at any location, as well as the heat enthalpy at the nodes of the Rankine cycle during the thermodynamic processes, provided the quantity of waste to combust is known, as well as the value of the low heating value.

\subsection{Comparison between Manually-Calculated and Software-Generated Values on: Energy Potentials and Power Plant Capacity}

The appropriate way to validate the efficiency of the software developed can be validated by comparing the manually-calculated values to the values obtained from the software package [65]. The values presented in Table 7 show that the accuracy of the software is $>99 \%$. This software can be used to predict the energy and power potentials of MSW in any location at any time, provided the weight and the low heating value are known. Nevertheless, it will excellently predict the quantity of work or heat involved in each of the power plant's equipment, as well as the capacity of the required boiler, turbine, and condenser that will convert the MSW to electrical energy.

Table 7. Comparison of manually-calculated and software-generated values.

\begin{tabular}{|c|c|c|}
\hline Parameters & Manually-Calculated Values & Software-Generated Values \\
\hline Energy potential $\left(E P_{m s w}\right)$ & $3,243,536.0 \mathrm{~kW}$ & $3,243,536.0 \mathrm{~kW}$ \\
\hline Electrical power potential $\left(E P P_{m s w}\right)$ & $40,544.3 \mathrm{~kW}$ & $40,544.3 \mathrm{~kW}$ \\
\hline Power to grid $(G P)$ & $27.36732 \mathrm{MW}$ & 27.36733 MW \\
\hline Work output of the high-pressure turbine $\left(W_{T_{12}}\right)$ & $445.0 \mathrm{~kJ} / \mathrm{kg}$ & $445.0 \mathrm{KJ} / \mathrm{kg}$ \\
\hline Heat supplied during reheat process $\left(Q_{26}\right)$ & $498.0 \mathrm{~kJ} / \mathrm{kg}$ & $498.0 \mathrm{~kJ} / \mathrm{kg}$ \\
\hline Dryness fraction at outlet of low-pressure turbine $\left(x_{7}\right)$ & 0.88 & 0.88 \\
\hline Steam enthalpy at outlet of low-pressure turbine $\left(h_{7}\right)$ & $2257.44 \mathrm{~kJ} / \mathrm{kg}$ & $2257.44 \mathrm{~kJ} / \mathrm{kg}$ \\
\hline Work output of low-pressure turbine $\left(W_{T_{67}}\right)$ & $1009.56 \mathrm{~kJ} / \mathrm{kg}$ & $1009.56 \mathrm{~kJ} / \mathrm{kg}$ \\
\hline Total work output of turbine $\left(W_{T_{12}}+W_{T_{67}}\right), W_{T}$ & $1454.56 \mathrm{~kJ} / \mathrm{kg}$ & $1454.56 \mathrm{~kJ} / \mathrm{kg}$ \\
\hline Heat rejected from condenser $\left(\mathrm{Q}_{37}\right)=\mathrm{Q}_{\mathrm{C}}$ & $2145.44 \mathrm{~kJ} / \mathrm{kg}$ & $2145.44 \mathrm{~kJ} / \mathrm{kg}$ \\
\hline Heat supplied into the boiler $\left(\mathrm{Q}_{13}\right)$ & $3102.0 \mathrm{~kJ} / \mathrm{kg}$ & $3102.0 \mathrm{~kJ} / \mathrm{kg}$ \\
\hline Total heat supplied to the steam in the boiler $\left(\mathrm{Q}_{\mathrm{B}}\right)$ & $3600.0 \mathrm{~kJ} / \mathrm{kg}$ & $3600.0 \mathrm{~kJ} / \mathrm{kg}$ \\
\hline Cycle efficiency $\left(S_{\mathrm{C}}\right)$ & $40.40 \%$ & $40.40 \%$ \\
\hline Net heat supplied to the system $\left(\mathrm{Q}_{\mathrm{Net}}\right)$ & $1454.56 \mathrm{~kJ} / \mathrm{kg}$ & $1454.56 \mathrm{~kJ} / \mathrm{kg}$ \\
\hline Steam mass flow rate $\left(\dot{m}_{S}\right)$ & $27.87 \mathrm{~kg} / \mathrm{s}$ & $27.87 \mathrm{~kg} / \mathrm{s}$ \\
\hline Specific steam consumption (SSC) & $2.48 \mathrm{~kg} / \mathrm{kWh}$ & $2.47 \mathrm{~kg} / \mathrm{kWh}$ \\
\hline MSW (fuel) consumption rate $\left(\mathrm{m}_{\mathrm{f}}\right)$ & 22.58 tons $/ \mathrm{h}$ & 22.58 tons $/ \mathrm{h}$ \\
\hline Boiler power $\left(Q_{B P}\right)$ & $100,345.88 \mathrm{~kW}$ & $100,345.89 \mathrm{~kW}$ \\
\hline Turbine power $\left(Q_{T P}\right)$ & $40,540.20 \mathrm{~kW}$ & $40,544.20 \mathrm{~kW}$ \\
\hline Condenser power $\left(Q_{C P}\right)$ & $59,801.68 \mathrm{~kW}$ & $59,801.68 \mathrm{~kW}$ \\
\hline
\end{tabular}

\section{Conclusions}

The software developed can effectively serve as a supporting system for the selection of the appropriate capacity of the steam power plant to convert any quantity of MSW as fuel to energy. The results obtained revealed that a steam power plant of about $100 \mathrm{MW}$ power of boiler, with about $40 \mathrm{MW}$ power of turbine and $60 \mathrm{MW}$ power of condenser with a steam mass flow rate of about $28 \mathrm{~kg} / \mathrm{s}$, will convert about 584 tons of municipal solid waste (MSW) with $20 \mathrm{MJ} / \mathrm{kg}$ heating value to electrical power potential of about $41 \mathrm{MW}$, and energy potential of about $3243 \mathrm{MWh}$. The comparison of the results obtained by manual calculation and that of the software shows an accuracy greater than $99 \%$. It is concluded that the software will successfully predict the energy and electrical power potentials of MSW, and the power to grid potentials in any quantity of combustible waste fractions at any 
time, irrespective of geographical variations. It will also predict the capacities of individual components in the power plant required to convert the waste to energy, provided the quantity of the municipal solid waste (MSW) to be converted in tons and the net heating value of the MSW (MJ/kg) is supplied. The software will also determine the cycle efficiency of the power plant, the steam mass flow rate, and the MSW (fuel) consumption.

Author Contributions: R.A.I. collected the literature and data, developed the software, inputted data into the software and prepared the manuscript; I.F.T. interpreted the data, analyzed the results, and designed the power plant capacity; B.O.A. prepared the algorithm used to develop the soft code of the software, supervised the experimentation, and edited the manuscript text. All authors have read and agreed to the published version of the manuscript.

Funding: This research was funded by the authors without any financial aid from an external body.

Acknowledgments: The authors appreciate the technologists in the research laboratories of Landmark University and the Federal University of Technology Akure for their support during experimentation.

Conflicts of Interest: The authors declare no conflict of interest of any kind.

\section{References}

1. Omari, A.; Said, M.; Njau, K.; John, G.; Mtul, P. Energy Recovery routes from Municipal Solid Waste, A case study of ArushaTanzania. J. Energy Technol. Policy 2014, 4. Available online: https://www.iiste.org/Journals/index.php/JETP/article/view/1315 7 (accessed on 7 May 2021).

2. Titiladunayo, I.F.; Akinnuli, B.O.; Ibikunle, R.A.; Agboola, O.O.; Ogunsemi, B.T. Analysis of combustible municipal solid waste fractions as fuel for energy production: Exploring its physicochemical and thermal characteristics. Int. J. Civil. Eng. Technol. 2018, 9, 1557-1575. Available online: http://www.iaeme.com/MasterAdmin/Journal_uploads/IJCIET/VOLUME_9_ISSUE_13 /IJCIET_09_13_157.pdf (accessed on 20 December 2018).

3. Islam, K.M.N. Municipal solid waste to energy generation in Bangladesh: Possible scenarios to generate renewable electricity in Dhaka and Chittagong city. J. Renew. Energy 2016, 1-16. Available online: http:/ / www.hindawi.com/journals (accessed on 25 November 2017).

4. Ibikunle, R.A.; Titiladunayo, I.F.; Lukman, A.F.; Dahunsi, S.O.; Akeju, E.A. Municipal solid waste sampling, quantification, and seasonal characterization for power evaluation: Energy potential and statistical modelling. Fuel 2020, 277, 118122. [CrossRef]

5. Ibikunle, R.A. Investigating municipal solid waste generation and management in Ilorin for possible integrated wastemanagement system. J. Mater. Cycles Waste Manag. 2021, 23, 1239-1257. [CrossRef]

6. Johari, A.; Hashim, H.; Mat, R.; Alias, H.; Hasshim, M.H.; Rozainee, M. Generalization, formulation, and heat contents of simulated MSW with moisture content. J. Eng. Sci. Technol. 2012, 7, 701-710. Available online: http://jestec.taylors.edu.my/Vol\% 207\%20Issue\%206\%20December\%2012/Vol7_.2012 (accessed on 5 May 2021).

7. Ibikunle, R.A.; Titiladunayo, I.F.; Akinnuli, B.O.; Dahunsi, S.O.; Olayanju, T.M.A. Estimation of power generation from municipal solid wastes: A case study of Ilorin metropolis. Nigeria. Energy Rep. 2019, 9, 126-135. [CrossRef]

8. Hoornweg, D.; Bhada-Tata, P. What a Waste: A Global Review of Solid Waste Management; Urban Development Series; Knowledge Papers no. 15; World Bank: Washington, DC, USA, 2012. Available online: https://openknowledge.worldbank.org/handle/1098 6/17388 (accessed on 5 May 2021).

9. Parashar, C.K.; Das, P.; Samanta, S.; Ganguly, A.; Chatterjee, P.K. Municipal Solid Wastes-A Promising Sustainable Source of Energy: A Review on Different Waste-to-Energy Conversion Technologies. Energy Recovery Processes from Wastes. 2019, pp. 151-163. Available online: https:/ / link.springer.com/chapter/10.1007/978-981-32-9228-4_13 (accessed on 5 May 2021).

10. Ibikunle, R.A.; Titiladunayo, I.F.; Dahunsi, S.O.; Akeju, E.A.; Osueke, C.O. Characterization and projection of dry season municipal solid waste for energy production in Ilorin metropolis, Nigeria. J. Waste Manag. Res. 2021, 1-10. [CrossRef]

11. World Bank. Sustainable Energy for All Database from SE4ALL Global Tracking Framework Led Jointly by the World Bank International Energy Agency, and Energy Management Assistance Programme. Available online: https://data.worldbank.org (accessed on 24 April 2018).

12. Akhator, E.P.; Obonor, A.I.; Ezemonye, L.I. Electricity generation in Nigeria from municipal solid waste using the Swedish Waste-to-Energy Model. J. Appl. Sci. Environ. Manag. 2016, 20, 635-643. [CrossRef]

13. Ogunjuyigbe, A.S.O.; Ayodele, T.R.; Alao, M.A. Electricity generation from municipal solid waste in some selected cities of Nigeria: An assessment of feasibility, potential technologies. J. Renew. Sustain. Energy Rev. 2017, 80, 149-162. [CrossRef]

14. Rasmus, L.; Brian, V.M. Large combined heat and power plants in sustainable energy systems. Appl. Energy 2015, 142, 389-395. Available online: https:/ /ideas.repec.org/a/eee/appene/v142y2015icp389-395.html (accessed on 4 April 2021).

15. Tsolas, S.D.; Karim, M.N.; Hasan, M.M.F. Optimization of water-energy nexus: A network representation-based graphical approach. Appl. Energy 2018, 224, 230-250. [CrossRef]

16. Xuerui, G.; Yong, Z.; Shibao, L.; Qianyun, C.; Tingli, A.; Xinxueqi, H.; La, Z. Impact of coal power production on sustainable water resources management in the coal-fired power energy bases of Northern China. Appl. Energy 2019, 250, 821-833. 
17. Do, W.K.; Tong, S.K.; Kwang, B.H.; Jung, K.P. The effect of firing biogas on the performance and operating characteristics of simple and recuperative cycle gas turbine combined heat and power systems. Appl. Energy 2012, 93, 215-228.

18. Njoku, N.; Lamond, J.; Everett, G.; Manu, P. An overview of municipal solid waste management in developing and developed economies: Analysis of practices andcontributions to urban flooding in Sub-Saharan Africa. In Proceedings of the 12th International Post Graduate Research Conference, Media City, UK, 10-12 June 2015. [CrossRef]

19. Ibikunle, R.A.; Lukman, A.F.; Titiladunayo, I.F.; Akeju, E.A.; Dahunsi, S.O. Modeling and robust prediction of high heating values of municipal solid waste based on ultimate analysis. Energy Sources Part A Recovery Util. Environ. Effects 2020. [CrossRef]

20. Worldometer-Real Time Statistics (Population by Country). Available online: https://www.worldometers.info2019 (accessed on 3 May 2019).

21. Hongtao, W.; Yongfeng, N. Municipal Solid Waste Characteristics and Management in China. J. Air Waste Manag. Assoc. 2001, 51, 250-263. [CrossRef]

22. Kosuke, K.; Tomohiro, T. Revisiting estimates of municipal solid waste generation per capita and their reliability. J. Mater. Cycles Waste Manag. 2016, 18, 1-3.

23. U.S. Energy Information Administration (U.S. EIA). Electricity in the United States is Produced (Generated) with Diverse Energy Sources and Technologies. 2020. Available online: https://www.eia.gov/energyexplained/electricity/electricity-in-the-us.php (accessed on 4 July 2020).

24. United Nations Environmental Programme (UNEP). Euthopia Marching towards Africa's First Waste-to-Energy Plant: Africa News. 2017. Available online: http:/ / www.africanews.com/2017/11/25/ethiopia-marching-towards-africas-first-waste-toenergy-plant-unep (accessed on 20 December 2018).

25. Oladende, O. 12 Nigerian Power Plants Produced Zero Megawatt Electricity on Christmas Day. Premiums Times (News). 4 January 2017. Available online: https://www.premiumtimesng.com/news/headlines/219590-12-nigerian-power-plantsproduced-zero-megawatt-electricity-christmas-day.html (accessed on 25 June 2021).

26. Larmuth, J.; Cuellar, A. An updated review of South African CSP projects under the renewable energy independent power producer procurement programme (REIPPPP). In AIP Conference Proceedings; AIP Publishing LLC.: Melville, NY, USA, 2019; Volume 2126, p. 040001. [CrossRef]

27. Ibikunle, R.A. Decision Support System for Power Plant Design Using Available Municipal Solid Waste in Ilorin Metropolis as Fuel. Ph.D. Thesis, Federal University of Technology, Akure, Nigeria, 2019.

28. Mareck, J.D.; Roger, R.F. Decision Support Systems. In Encyclopedia of Library and Information Sciences, 2nd ed.; Kent, A., Ed.; Marcel Dekker, Inc.: New York, NY, USA, 2002.

29. Claudio, B. Decision Support Systems Development: A Methodological Approach. J. Appl. Bus. Inf. Syst. 2011, 2, 151-158. Available online: http:/ / www.jabis.ro/2011/4/0204012011.pdf (accessed on 1 May 2021).

30. Konstantinos, I.; Georgios, T.; Garyfallos, A.; Zacharoula, A.; Eleni, Z. A Spatial Decision Support System Framework for the Evaluation of Biomass Energy Production Locations: Case Study in the Regional Unit of Drama Greece. Sustainability 2018, 10, 531-553. [CrossRef]

31. Fatima, C.C.D.; Erhard, W.P. A decision support system for power plant design. Eur. J. Oper. Res. 1998, 109, 310-320. Available online: http:/ / www.sciencedirect.com/science/article/pii/S0377-2217(98)00059-91998 (accessed on 5 July 2019).

32. Konstantinos, I.; Paragnotis, L.; Arabatzis, Z. Development of a decision support system for the study of an area after the occurrence of forest fire. Int. J. Sustain. Soc. 2011, 3, 5-53. [CrossRef]

33. NT ENVR-01 (Nordtest Method). Solid Waste Municipal Sampling and Characterization. Published by Nordtest Tekniikantie 12, FIN-02150 ESPOO FINLAND. 1998. Available online: http:/ / www.nordtest.info/wp/1995/05/14/solid-waste-municipalsampling-and-characterisation-nt-envir-001/ (accessed on 7 July 2019).

34. Issam, A.K.A.; Maria, M.B.; Salam, A.T.; Saheed, H.Q.; Kassinos, D.B. Solid waste characterization, qualification, and management practices in developing countries, a case study: Nubulus district-palestine. J. Environ. Manag. 2010, 91, 1131-1138.

35. Vairam, S.; Ramesh, S. Engineering Chemistry; John Wiley and Sons Ltd.: Southern Gate, Chichester, UK, 2013.

36. Shi, H.; Maphinpey, N.; Aqsha, A.; Silbermann, R. Characterization, thermochemical conversion studies and heating value modeling of municipal solid waste. J. Waste Manag. 2016, 48, 34-47. [CrossRef]

37. Ibikunle, R.A.; Titiladunayo, I.F.; Akinnuli, B.O.; Lukman, A.F.; Ikubanni, P.P.; Agboola, O.O. Modeling the energy content of municipal solid waste and determination of its physicochemical correlation using multiple regression analysis. Int. J. Mech. Eng Technol. 2018, 9, 220-232.

38. Kumar, J.S.; Subbaiah, K.V.; Rao, P.P. Waste to energy-a case study of eluru city, andhara pradesh. Int. J. Environ. Sci. 2010, 2, 151-162.

39. Daura, L.A. Electricity generation potential of municipal solid waste in kanometropolis. J. Sci. Eng. Res. 2016, 3, 157-161.

40. Muhammad, A.; Farid, N.A.; Ab Saman, K. The energy potential of municipal solid waste for power generation in indonesia. $J$. Mech. 2014, 2, 42-54.

41. Bright Hub Engineering (BHE). Conversion Efficiencies in the Steam Power Plants. 2016. Available online: www. brighthubengineering.com/power-plants/72369-compare-thefficiency (accessed on 22 February 2017).

42. Kapooria, R.K.; Kumar, S.; Kasana, K.S. An analysis of a thermal power plant working on a Rankine cycle: A theoretical investigation. J. Energy S. Afr. 2008, 19, 77-83. [CrossRef] 
43. Somplak, R.; Ferdan, T.; Palvas, M.; Palvas, M.; Popela, P. Waste-to-energy facility planning under uncertain circumstances. J. Appl. Therm. Eng. 2013, 61, 106-114. [CrossRef]

44. Karlsson, L.; Jonsson, T.L. Pre-Feasibility Study of a Waste-to-Energy Plant in Chisinau, Moldova. Uppsala Universitet. 2012. Available online: https:/ /www.diva-portal.org/smash/get/diva2:510286/FULLTEXT01.pdf (accessed on 25 October 2016).

45. Arabkoohsar, A. Combined steam based high-temperature heat and power storage with an Organic Rankine Cycle, an efficient mechanical electricity storage technology. J. Clean. Prod. 2020, 247, 119098. [CrossRef]

46. Loni, R.; Najafi, G.; Bellos, E.; Rajaee, F.; Said, F.; Mazlan, M. A review of industrial waste heat recovery system for power generation with Organic Rankine Cycle: Recent challenges and future outlook. J. Clean. Prod. 2020, 125070. [CrossRef]

47. Jordi, B. Development and Implementation of a Nuclear Power Plant Steam Turbine Model in the System Code ATHLET. Master Thesis, Technische Universitat Muchen, Muchen, Germany, 2011.

48. Hesham, G.I. Steam Power Plant Design Upgrading (Case Study: Khoms Steam Power Plant). J. Energy Environ. Res. 2011, 1, 202. [CrossRef]

49. Eastop, T.D.; Mc Conkey, A. Applied Thermodynamics, 5th ed.; Dorling Kindersley Pvt. Ltd.: Delhi, India, 2014.

50. Sadhu, S. Handbook of Mechanical Engineering; S. Chand \& Company Ltd.: New Delhi, India, 2011.

51. Ting, Y.; Noam, L. Thermodynamic analysis of hybrid Rankine cycles using multiple heat sources of different temperatures. Appl. Energy 2018, 222, 564-583. [CrossRef]

52. Winterbone, O.E.; Turan, A. Advanced Thermodynamics for Engineers; John Wiley and Sons Inc.: New York, NY, USA; Toronto, ON, Canada, 2015.

53. Ibrahim, D.; Yusuf, B. Fundamentals of Energy System. Integrated Energy Systems for Multigeneration (Elsevier Inc.). 2019. Available online: https:/ / www.elsevier.com/books/integrated-energy-systems-formultigeneration/dincer/978-0-12-809943-8 (accessed on 7 May 2021). [CrossRef]

54. Oyedepo, S.O.; Fakeye, B.A.; Mabinuori, B.; Babalola, P.O.; Leramo, R.O.; Kilanko, O.; Dirisu, J.O.; Udo, M.; Efemwenkiekie, U.K.; Oyebanji, J.A. Thermodynamics analysis and performance optimization of a reheat-Regenerative steam turbine power plant with feed water heaters. Fuel 2020, 280, 118577. [CrossRef]

55. Maxwell, U.N. Solid waste generation and disposal in a nigerian city: An empirical analysis in onitsha metropolis. J. Environ. Manag. Saf. 2010, 1, 180-191.

56. Rominiyi, O.L.; Fapetu, O.P.; Owolabi, J.O.; Adaramola, B.A. Determination of energycontent of the municipal solid waste of Ado-Ekiti Metropolis, Southwest, Nigeria. Curr. J. Appl. Sci. Technol. 2017, 23, 1-11. [CrossRef]

57. U.S. Energy Information Administration (USEIA). Biomass Explained. Waste-to-Energy (Municipal Solid Waste) Energy Recovery from Municipal Solid Waste. 2018. Available online: https://www.eia.gov/state/seds/sep_fuel/notes/use_glossary.pdf (accessed on 7 July 2019).

58. Swedish Waste Management (SWM). 2015. Available online: www.arfallaverage.se/fileadmin/uploads/Rapporter/SWM2015. pdf (accessed on 20 June 2016).

59. Scarlet, W.; Dellemand, J.F.; Monforti-Ferrano, F.; Nita, V. The role of biomass and bioenergy in a future bioeconomy: Policies and facts. Environ. Dev. 2015, 15, 3-34. [CrossRef]

60. Wale, B. Energy. Energy Consult Powering Clean Energy Future, Solid Waste Management in Nigeria. 2018. Available online: https: / / www.bioenergyconsult.com/solid-waste-nigeria (accessed on 20 December 2018).

61. U.S. IEA Statistics. Ghana-Combustible Renewables and Waste (\% of Total Energy). OECD/IEA. 2014. Available online: http: / / www.iea.org/stats/index.asp (accessed on 29 June 2021).

62. Deep Resource World Press (DRW). Energy Conversion Factors. 2012. Available online: https://deepresource.worldpress.com/ 2012/04/23/energyrelatedconversionfactors (accessed on 14 September 2018).

63. World Nuclear Association (WNA): Heat Values of Various Fuels. 2018. Available online: www.world-nuclear.org (accessed on 14 October 2018).

64. Ibadan Electricity Distribution Company (IBEDC). Kwara Needs 270 MW for 24-Hour Electricity. 2016. Available online: https: / / www.ilorin.info / fullnews.php?id=18082 (accessed on 3 October 2018).

65. Akinnuli, B.; Ogedengbe, T.I.; Oladosu, K.O. Computer Aided Design and Drafting of Helical gears. J. Eng. Trends Appl. Sci. 2012, 3, 959-968. 